4

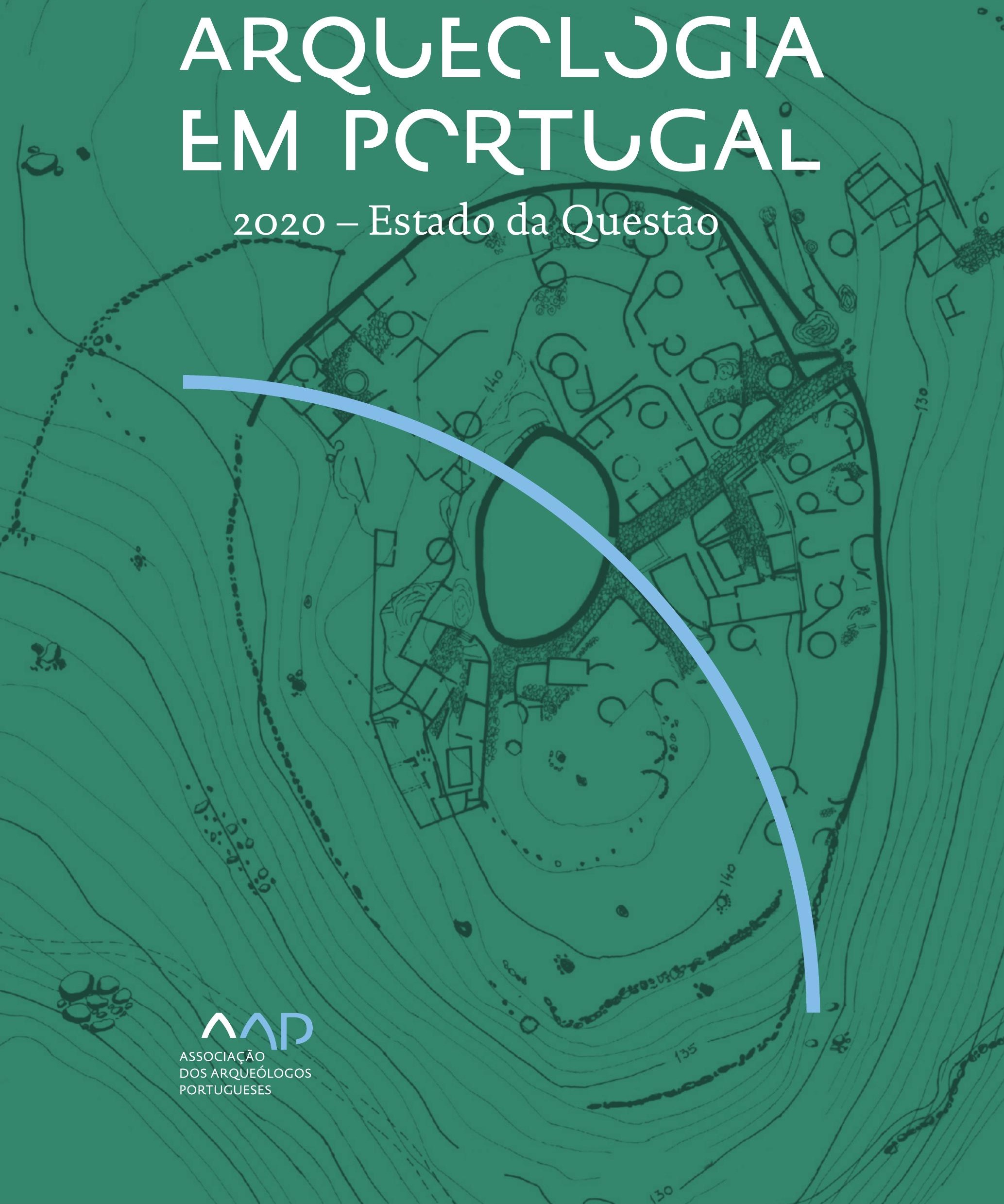


Coordenação editorial: José Morais Arnaud, César Neves e Andrea Martins Design gráfico: Flatland Design

AAP - ISBN: 978-972-9451-89-8

CITCEM - ISBN: 978-989-8970-25-1

Associação dos Arqueólogos Portugueses e CITCEM

Lisboa, 2020

O conteúdo dos artigos é da inteira responsabilidade dos autores. Sendo assim a Associação dos Arqueólogos Portugueses declina qualquer responsabilidade por eventuais equívocos ou questões de ordem ética e legal.

Desenho de capa:

Planta do castro de Monte Mozinho (Museu Municipal de Penafiel).

\section{$\hat{\wedge} \mathrm{P}$}

DOS ARQUEÓLOGOS PORTUGUESES

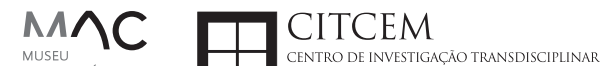
MUSEU
ARQUELLÓGICO
DO CARMO
U.PORTO

FLUP FACULDADE DE LETRAS
UNIVERSIDADE DO PORTO

Apoio

EC para a Ciência 


\section{Índice}

15 Prefácio

José Morais Arnaud

\section{Historiografia e Teoria}

17 Território, comunidade, memória e emoção: a contribuição da história da arqueologia (algumas primeiras e breves reflexões)

Ana Cristina Martins

25 Como descolonizar a arqueologia portuguesa?

Rui Gomes Coelho

41 Arqueologia e Modernidade: uma revisitação pessoal e breve de alguns aspetos da obra homónima de Julian Thomas de 2004

Vítor Oliveira Jorge

57 Dados para a História das Mulheres na Arqueologia portuguesa, dos finais do século XIX aos inícios do século XX: números, nomes e tabelas

Filipa Dimas / Mariana Diniz

73 Retractos da arqueologia portuguesa na imprensa: (in)visibilidades no feminino

Catarina Costeira / Elsa Luís

85 Arqueologia e Arqueólogos no Norte de Portugal Jacinta Bugalhão

101 Vieira Guimarães (1864-1939) e a arqueologia em Tomar: uma abordagem sobre o território e as gentes

João Amendoeira Peixoto / Ana Cristina Martins

115 Os memoráveis? A arqueologia algarvia na imprensa nacional e regional na presente centúria (2001-2019): características, visões do(s) passado(s) e a arqueologia

enquanto marca

Frederico Agosto / João Silva

129 A Evolução da Arqueologia Urbana e a Valorização Patrimonial no Barlavento Algarvio: Os casos de Portimão e Silves

Artur Mateus / Diogo Varandas / Rafael Boavida

\section{Gestão, Valorização e Salvaguarda do Património}

145 O Caderno Reivindicativo e as condições de trabalho em Arqueologia Miguel Rocha / Liliana Matias Carvalho / Regis Barbosa / Mauro Correia / Sara Simões / Jacinta Bugalhão / Sara Brito / Liliana Veríssimo Carvalho / Richard Peace / Pedro Peça / Cézer Santos

155 Os Estudos de Impacte Patrimonial como elemento para uma estratégia sustentável de minimização de impactes no âmbito de reconversões agrícolas Tiago do Pereiro

165 Salvaguarda de Património arqueológico em operações florestais: gestão e sensibilização Filipa Bragança / Gertrudes Zambujo / Sandra Lourenço / Belém Paiva / Carlos Banha / Frederico Tatá Regala / Helena Moura / Jacinta Bugalhão / João Marques / José Correia / Pedro Faria / Samuel Melro

179 Os valores do Património: uma investigação sobre os Sítios Pré-históricos de Arte Rupestre do Vale do Rio Côa e de Siega Verde José Paulo Francisco 
189 Conjugando recursos arqueológicos e naturais para potenciar as visitas ao Geoparque Litoral de Viana do Castelo (Noroeste de Portugal)

Hugo A. Sampaio / Ana M.S. Bettencourt / Susana Marinho / Ricardo Carvalhido

203 Áreas de Potencial Arqueológico na Região do Médio Tejo: Modelo Espacial Preditivo Rita Ferreira Anastácio / Ana Filipa Martins / Luiz Oosterbeek

223 Património Arqueológico e Gestão Territorial: O contributo da Arqueologia para a revisão do PDM de Avis

Ana Cristina Ribeiro

237 A coleção arqueológica do extinto Museu Municipal do Porto - Origens, Percursos e Estudos

Sónia Couto

251 Valpaços - uma nova carta arqueológica

Pedro Pereira / Maria de Fátima Casares Machado

263 Arqueologia na Cidade de Peniche

Adriano Constantino / Luís Rendeiro

273 Arqueologia Urbana: a cidade de Lagos como caso de Estudo Cátia Neto

285 Estratégias de promoção do património cultural subaquático nos Açores. O caso da ilha do Faial

José Luís Neto / José Bettencourt / Luís Borges / Pedro Parreira

297 Carta Arqueológica da Cidade Velha: Uma primeira abordagem

Jaylson Monteiro / Nireide Tavares / Sara da Veiga / Claudino Ramos / Edson Brito /

Carlos Carvalho / Francisco Moreira / Adalberto Tavares

311 Antropologia Virtual: novas metodologias para a análise morfológica e funcional Ricardo Miguel Godinho / Célia Gonçalves

\section{Didáctica da Arqueologia}

327 Como os projetos de Arqueologia podem contribuir para uma comunidade culturalmente mais consciente Alexandra Figueiredo / Claúdio Monteiro / Adolfo Silveira / Ricardo Lopes

337 Educação Patrimonial - Um cidadão esclarecido é um cidadão ativo! Ana Paula Almeida

351 A aproximação da Arqueologia à sala de aula: um caso de estudo no $3^{\circ}$ ciclo do Ensino Básico Luís Serrão Gil

363 Arqueologia 3.o - Pensar e comunicar a Arqueologia para um futuro sustentável Mónica Rolo

377 “Conversa de Arqueólogos" - Divulgar a Arqueologia em tempos de Pandemia Diogo Teixeira Dias

389 Escola Profissional de Arqueologia: desafios e oportunidades Susana Nunes / Dulcineia Pinto / Júlia Silva / Ana Mascarenhas

399 Os Museus de Arqueologia e os Jovens: a oferta educativa para o público adolescente Beatriz Correia Barata / Leonor Medeiros

411 O museu universitário como mediador entre a ciência e a sociedade: o exemplo da secção de arqueologia no Museu de História Natural e da Ciência da Universidade do Porto (MHNC-UP)

Rita Gaspar 
421 Museu de Lanifícios: Real Fábrica de Panos. Atividades no âmbito da Arqueologia Beatriz Correia Barata / Rita Salvado

427 Arqueologia Pública e o caso da localidade da Mata (Torres Novas) Cláudia Manso / Ana Rita Ferreira / Cristiana Ferreira / Vanessa Cardoso Antunes

431 Do sítio arqueológico ao museu: um percurso (também) didático Lídia Fernandes

447 Estão todos convidados para a Festa! E para dançar também... O projecto do Serviço Educativo do Museu Arqueológico do Carmo na $5^{\underline{a}}$ Edição da Festa da Arqueologia Rita Pires dos Santos

459 O “Clã de Carenque”, um projeto didático de arqueologia Eduardo Gonzalez Rocha

469 Mediação cultural: peixe que puxa carroça nas Ruínas Romanas de Troia Inês Vaz Pinto / Ana Patrícia Magalhães / Patrícia Brum / Filipa Santos

481 Didática Arqueológica, experiências do Projeto Mértola Vila Museu Maria de Fátima Palma / Clara Rodrigues / Susana Gómez / Lígia Rafael

\section{Arte Rupestre}

497 Os inventários de arte rupestre em Portugal Mila Simões de Abreu

513 O projeto FIRST-ART - conservação, documentação e gestão das primeiras manifestações de arte rupestre no Sudoeste da Península Ibérica: as grutas do Escoural e Maltravieso Sara Garcês / Hipólito Collado / José Julio García Arranz / Luiz Oosterbeek / António Carlos Silva / Pierluigi Rosina / Hugo Gomes / Anabela Borralheiro Pereira / George Nash / Esmeralda Gomes / Nelson Almeida / Carlos Carpetudo

523 Trabalhos de documentação de arte paleolítica realizados no âmbito do projeto PalæoCôa André Tomás Santos / António Fernando Barbosa / Luís Luís / Marcelo Silvestre / Thierry Aubry

537 Imagens fantasmagóricas, silhuetas elusivas: as figuras humanas na arte do Paleolítico Superior da região do Côa Mário Reis

$55^{1}$ Os motivos zoomórficos representados nas placas de tear de Vila Nova de São Pedro (Azambuja, Portugal) Andrea Martins / César Neves / José M. Arnaud / Mariana Diniz

571 Arte Rupestre do Monte de Góios (Lanhelas, Caminha). Síntese dos resultados dos trabalhos efectuados em 2007-2009 Mário Varela Gomes

599 Gravuras rupestres de barquiformes no Monte de S. Romão, Guimarães, Noroeste de Portugal Daniela Cardoso

613 Círculos segmentados gravados na Bacia do Rio Lima (Noroeste de Portugal): contributos para o seu estudo Diogo Marinho / Ana M.S. Bettencourt / Hugo Aluai Sampaio

631 Equídeos gravados no curso inferior do Rio Mouro, Monção (NW Portugal). Análise preliminar Coutinho, L.M. / Bettencourt, A.M.S / Sampaio, Hugo A.S

645 Paletas na Arte Rupestre do Noroeste de Portugal. Inventário preliminar Bruna Sousa Afonso / Ana M. S. Bettencourt / Hugo A. Sampaio 


\section{Pré-História}

661 O projeto Miño/Minho: balanço de quatro anos de trabalhos arqueológicos Sérgio Monteiro-Rodrigues / João Pedro Cunha-Ribeiro / Eduardo Méndez-Quintas / Carlos Ferreira / Pedro Xavier / José Meireles / Alberto Gomes / Manuel Santonja / Alfredo Pérez-González

677 A ocupação paleolítica da margem esquerda do Baixo Minho: a indústria lítica do sítio de Pedreiras 2 (Monção, Portugal) e a sua integração no contexto regional Carlos Ferreira / João Pedro Cunha-Ribeiro / Sérgio Monteiro-Rodrigues / Eduardo Méndez-Quintas / Pedro Xavier / José Meireles / Alberto Gomes / Manuel Santonja / Alfredo Pérez-González

693 O sítio acheulense do Plistocénico médio da Gruta da Aroeira Joan Daura / Montserrat Sanz / Filipa Rodrigues / Pedro Souto / João Zilhão

703 As sociedades neandertais no Barlavento algarvio: modelos preditivos com recurso aos SIG

Daniela Maio

715 A utilização de quartzo durante o Paleolítico Superior no território dos vales dos rios Vouga e Côa

Cristina Gameiro / Thierry Aubry / Bárbara Costa / Sérgio Gomes / Luís Luís / Carmen Manzano / André Tomás Santos

733 Uma perspetiva diacrónica da ocupação do concheiro do Cabeço da Amoreira (Muge, Portugal) a partir da tecnologia lítica Joana Belmiro / João Cascalheira / Célia Gonçalves

745 Novos dados sobre a Pré-história Antiga no concelho de Palmela. A intervenção arqueológica no sítio do Poceirão I

Michelle Teixeira Santos

757 Problemas em torno de Datas Absolutas Pré-Históricas no Norte do Alentejo Jorge de Oliveira

771 Povoamento pré-histórico nas áreas montanhosas do NO de Portugal: o Abrigo 1 de Vale de Cerdeira Pedro Xavier / José Meireles / Carlos Alves

783 Apreciação do povoamento do Neolítico Inicial na Baixa Bacia do Douro. A Lavra I (Serra da Aboboreira) como caso de estudo Maria de Jesus Sanches

797 O Processo de Neolitização na Plataforma do Mondego: os dados do Sector C do Outeiro dos Castelos de Beijós (Carregal do Sal)

João Carlos de Senna-Martinez / José Manuel Quintã Ventura / Andreia Carvalho / Cíntia Maurício

823 Novos trabalhos na Lapa da Bugalheira (Almonda, Torres Novas) Filipa Rodrigues / Pedro Souto / Artur Ferreira / Alexandre Varanda / Luís Gomes / Helena Gomes / João Zilhão

837 A pedra polida e afeiçoada do sítio do Neolítico médio da Moita do Ourives (Benavente, Portugal)

César Neves

857 Casal do Outeiro (Encarnação, Mafra): novos contributos para o conhecimento do povoamento do Neolítico final na Península de Lisboa.

Cátia Delicado / Carlos Maneira e Costa / Marta Miranda / Ana Catarina Sousa

873 Stresse infantil, morbilidade e mortalidade no sítio arqueológico do Neolítico Final/ Calcolítico ( $4^{\circ}$ e $3^{\circ}$ milénio a.C.) do Monte do Carrascal 2 (Ferreira do Alentejo, Beja) Liliana Matias de Carvalho / Sofia N. Wasterlain 
885 Come together: O Conjunto Megalítico das Motas (Monção, Viana do Castelo) e as expressões Campaniformes do Alto Minho Ana Catarina Basílio / Rui Ramos

899 Trabalhos arqueológicos no sítio Calcolítico da Pedreira do Poio Carla Magalhães / João Muralha / Mário Reis / António Batarda Fernandes

913 O sítio arqueológico de Castanheiro do Vento. Da arquitectura do sítio à arquitectura de um território João Muralha Cardoso

925 Estudo zooarqueológico das faunas do Calcolítico final de Vila Nova de São Pedro (Azambuja, Portugal): Campanhas de 2017 e 2018 Cleia Detry / Ana Catarina Francisco / Mariana Diniz / Andrea Martins / César Neves / José Morais Arnaud

943 As faunas depositadas no Museu Arqueológico do Carmo provenientes de Vila Nova de São Pedro (Azambuja): as campanhas de 1937 a 1967 Ana Catarina Francisco / Cleia Detry / César Neves / Andrea Martins / Mariana Diniz / José Morais Arnaud

959 Análise funcional de material lítico em sílex do castro de Vila Nova de S. Pedro (Azambuja, Portugal): uma primeira abordagem Rafael Lima

971 O recinto da Folha do Ouro 1 (Serpa) no contexto dos recintos de fossos calcolíticos alentejanos

António Carlos Valera / Tiago do Pereiro / Pedro Valério / António M. Monge Soares

\section{Proto-História}

987 Produção de sal marinho na Idade do Bronze do noroeste Português. Alguns dados para uma reflexão

Ana M. S. Bettencourt / Sara Luz / Nuno Oliveira / Pedro P. Simões / Maria Isabel C. Alves / Emílio Abad-Vidal

1001 A estátua-menir do Pedrão ou de São Bartolomeu do Mar (Esposende, noroeste de Portugal) no contexto arqueológico da fachada costeira de entre os rios Neiva e Cávado Ana M. S. Bettencourt / Manuel Santos-Estévez / Pedro Pimenta Simões / Luís Gonçalves

1015 O Castro do Muro (Vandoma/Baltar, Paredes) - notas para uma biografia de ocupação da Idade do Bronze à Idade Média

Maria Antónia D. Silva / Ana M. S. Bettencourt / António Manuel S. P. Silva / Natália Félix

1031 Do Bronze Final à Idade Média - continuidades e hiatos na ocupação de Povoados em Oliveira de Azeméis João Tiago Tavares / Adriaan de Man

1041 As faunas do final da Idade do Bronze no Sul de Portugal: leituras desde o Outeiro do Circo (Beja)

Nelson J. Almeida / Íris Dias / Cleia Detry / Eduardo Porfírio / Miguel Serra

1055 A Espada do Monte das Oliveiras (Serpa) - uma arma do Bronze Pleno do Sudoeste Rui M. G. Monge Soares / Pedro Valério / Mariana Nabais / António M. Monge Soares

1065 São Julião da Branca (Albergaria-a-Velha) - Investigação e valorização de um povoado do Bronze Final

António Manuel S. P. Silva / Paulo A. P. Lemos / Sara Almeida e Silva / Edite Martins de Sá

1083 Do castro de S. João ao Mosteiro de Santa Clara: notícia de uma intervenção arqueológica, em Vila do Conde Rui Pinheiro 
1095 O castro de Ovil (Espinho), um quarto de século de investigação - resultados e questões em aberto

Jorge Fernando Salvador / António Manuel S. P. Silva

1111 O Castro de Salreu (Estarreja), um povoado proto-histórico no litoral do Entre Douro e Vouga

Sara Almeida e Silva / António Manuel S. P. Silva / Paulo A. P. Lemos / Edite Martins de Sá

1127 Castro de Nossa Senhora das Necessidades (Sernancelhe): uma primeira análise artefactual Telma Susana O. Ribeiro

${ }_{1141}$ A cividade de Bagunte. O estado atual da investigação Pedro Brochado de Almeida

1153 Zoomorfos na cerâmica da Idade do Ferro no NW Peninsular: inventário, cronologias e significado Nuno Oliveira / Cristina Seoane

1163 Vasos gregos em Portugal: diferentes maneiras de contar a história do intercâmbio cultural na Idade do Ferro

Daniela Ferreira

1175 Os exotica da necrópole da Idade do Ferro do Olival do Senhor dos Mártires (Alcácer do Sal) no seu contexto regional

Francisco B. Gomes

\section{Antiguidade Clássica e Tardia}

1191 O uso de madeira como combustível no sítio da Quinta de Crestelos (Baixo Sabor): da Idade do Ferro à Romanização Filipe Vaz / João Tereso / Sérgio Simões Pereira / José Sastre / Javier Larrazabal Galarza / Susana Cosme / José António Pereira / Israel Espi

1207 Cultivos de Época Romana no Baixo Sabor: continuidade em tempos de mudança? João Pedro Tereso / Sérgio Simões Pereira / Filipe Santos / Luís Seabra / Filipe Vaz

1221 A casa romana na Hispânia: aplicação dos modelos itálicos nas províncias ibéricas Fernanda Magalhães / Diego Machado / Manuela Martins

1235 As pinturas murais romanas da Rua General Sousa Machado, n. ${ }^{5}$ 1, Chaves José Carvalho

1243 Trás do Castelo (Vale de Mir, Pegarinhos, Alijó) - Uma exploração agrícola romana do Douro

Tony Silvino / Pedro Pereira

1255 A sequência de ocupação no quadrante sudeste de Bracara Augusta: as transformações de uma unidade doméstica Lara Fernandes / Manuela Martins

1263 Os Mosaicos com decoração geométrica e geométrico-vegetalista dos sítios arqueológicos da área do Conuentus Bracaraugustanus. Novas abordagens quanto à conservação, restauro, decoração e datação Maria de Fátima Abraços / Licínia Wrench

1277 “Casa Romana” do Castro de São Domingos (Cristelos, Lousada): Escavação, Estudo e Musealização Paulo André de P. Lemos

1291 A arqueobotânica no Castro de Guifões (Matosinhos, Noroeste de Portugal): O primeiro estudo carpológico

Luís Seabra / Andreia Arezes / Catarina Magalhães / José Varela / João Pedro Tereso 
1305 Um Horreum Augustano na Foz do Douro (Monte do Castelo de Gaia, Vila Nova de Gaia) Rui Ramos

1311 Ponderais romanos na Lusitânia: padrões, formas, materiais e contextos de utilização Diego Barrios Rodríguez

1323 Um almofariz centro-itálico na foz do Mondego

Marco Penajoia

1335 Estruturas romanas de Carnide - Lisboa Luísa Batalha / Mário Monteiro / Guilherme Cardoso

1347 O contexto funerário do sector da "necrópole NO" da Rua das Portas de S. Antão (Lisboa): o espaço, os artefactos, os indivíduos e a sua interconectividade na interpretação do passado Sílvia Loja, José Carlos Quaresma, Nelson Cabaço, Marina Lourenço, Sílvia Casimiro, Rodrigo Banha da Silva, Francisca Alves-Cardoso

${ }_{1361}$ Povoamento em época Romana na Amadora - resultados de um projeto pluridisciplinar Gisela Encarnação / Vanessa Dias

1371 A Arquitectura Residencial em Mirobriga (Santiago do Cacém): contributo a partir de um estudo de caso Filipe Sousa / Catarina Felício

${ }_{1385}$ O fim do ciclo. Saneamento e gestão de resíduos nos edifícios termais de Mirobriga (Santiago do Cacém)

Catarina Felício / Filipe Sousa

1399 Balsa, Topografia e Urbanismo de uma Cidade Portuária Vítor Silva Dias / João Pedro Bernardes / Celso Candeias / Cristina Tété Garcia

1413 No Largo das Mouras Velhas em Faro (2017): novas evidências da necrópole norte de Ossonoba e da sua ocupação medieval Ricardo Costeira da Silva / Paulo Botelho / Fernando Santos / Liliana Nunes

1429 Instrumentos de pesca recuperados numa fábrica de salga em Ossonoba (Faro) Inês Rasteiro / Ricardo Costeira da Silva / Paulo Botelho

1439 A Necrópole Romana do Eirô, Duas Igrejas (Penafiel): intervenção arqueológica de 2016 Laura Sousa / Teresa Soeiro

1457 Ritual, descarte ou afetividade? A presença de Canis lupus familiaris na Necrópole Noroeste de Olisipo (Lisboa)

Beatriz Calapez Santos / Sofia Simões Pereira / Rodrigo Banha da Silva / Sílvia Casimiro / Cleia Detry / Francisca Alves Cardoso

1467 Dinâmicas económicas em Bracara na Antiguidade Tardia Diego Machado / Manuela Martins / Fernanda Magalhães / Natália Botica

1479 Cerâmicas e Vidros da Antiguidade Tardia do Edifício sob a Igreja do Bom Jesus (Vila Nova de Gaia) Joaquim Filipe Ramos

1493 Novos contributos para a topografia histórica de Mértola no período romano e na Antiguidade Tardia Virgílio Lopes

\section{8. Época Medieval}

1511 Cerâmicas islâmicas no Garb setentrional "português": algumas evidências e incógnitas Constança dos Santos / Helena Catarino / Susana Gómez / Maria José Gonçalves / Isabel Inácio / Gonçalo Lopes / Jacinta Bugalhão / Sandra Cavaco / Jaquelina Covaneiro / Isabel Cristina Fernandes / Ana Sofia Gomes 
1525 Contributo para o conhecimento da cosmética islâmica, em Silves, durante a Idade Média Rosa Varela Gomes

1537 Yábura e o seu território - uma análise histórico-arqueológica de Évora entre os séculos VIII-XII José Rui Santos

1547 A encosta sul do Castelo de Palmela - resultados preliminares da escavação arqueológica Luís Filipe Pereira / Michelle Teixeira Santos

1559 A igreja de São Lourenço (Mouraria, Lisboa): um conjunto de silos e de cerâmica medieval islâmica

Andreia Filipa Moreira Rodrigues

1571 O registo material de movimentações populacionais no Médio Tejo, durante os séculos XII-XIII. Dois casos de "sunken featured buildings", nos concelhos de Cartaxo e Torres Novas Marco Liberato / Helena Santos / Nuno Santos

1585 O nordeste transmontano nos alvores da Idade média. Notas para reflexão Ana Maria da Costa Oliveira

1601 Sepulturas escavadas na rocha do Norte de Portugal e do Vale do Douro: primeiros resultados do Projecto SER-NPVD

Mário Jorge Barroca / César Guedes / Andreia Arezes / Ana Maria Oliveira

1619 "Portucalem Castrum Novum" entre o Mediterrâneo e o Atlântico: o estudo dos materiais cerâmicos alto-medievais do arqueossítio da rua de D. Hugo, nํ. 5 (Porto) João Luís Veloso

1627 A Alta Idade Média na fronteira de Lafões: notas preliminares sobre a Arqueologia no Concelho de Vouzela

Manuel Luís Real / Catarina Tente

1641 Um conjunto cerâmico medieval fora de portas: um breve testemunho aveirense Susana Temudo

${ }_{1651}$ Os Lóios do Porto: uma perspetiva integrada no panorama funerário da Baixa Idade Média à Época Moderna em meios urbanos em Portugal

Ana Lema Seabra

1659 O Caminho Português Interior de Santiago como eixo viário na Idade Média Pedro Azevedo

1665 Morfologia Urbana: Um exercício em torno do Castelo de Ourém André Donas-Botto / Jaqueline Pereira

1677 Intervenção arqueológica na Rua Marquês de Pombal/Largo do Espírito Santo (Bucelas, Loures)

Florbela Estêvão / Nathalie Antunes-Ferreira / Dário Ramos Neves / Inês Lisboa

1691 O Cemitério Medieval do Poço do Borratém e a espacialidade funerária na cidade de Lisboa Inês Belém / Vanessa Filipe / Vasco Noronha Vieira / Sónia Ferro / Rodrigo Banha da Silva

1705 Um Espaço Funerário Conventual do séc. XV em Lisboa: o caso do Convento de São Domingos da Cidade Sérgio Pedroso / Sílvia Casimiro / Rodrigo Banha da Silva / Francisca Alves Cardoso

\section{9. Época Moderna e Contemporânea}

1721 Arqueologia Moderna em Portugal: algumas reflexões críticas em torno da quantificação de conjuntos cerâmicos e suas inferências históricas e antropológicas Rodrigo Banha da Silva / André Bargão / Sara da Cruz Ferreira

1733 Faianças de dois contextos entre os finais do século XVI e XVIII do Palácio dos Condes de Penafiel, Lisboa

Martim Lopes / Tomás Mesquita 
1747 Um perfil de consumo do século XVIII na foz do Tejo: O caso do Mercado da Ribeira, Lisboa Sara da Cruz Ferreira / Rodrigo Banha da Silva / André Bargão

1761 Os Cachimbos dos Séculos XVII e XVIII do Palácio Mesquitela e Convento dos Inglesinhos (Lisboa)

Inês Simão / Marina Pinto / João Pimenta / Sara da Cruz Ferreira / André Bargão / Rodrigo Banha da Silva

1775 "Tomar os fumos da erua que chamão em Portugal erua sancta». Estudo de Cachimbos provenientes da Rua do Terreiro do Trigo, Lisboa

Miguel Martins de Sousa / José Pedro Henriques / Vanessa Galiza Filipe

1787 Cachimbos de Barro Caulínitico da Sé da Cidade Velha (República de Cabo Verde)

Rodrigo Banha da Silva / João Pimenta / Clementino Amaro

1801 Algumas considerações sobre espólio não cerâmico recuperado no Largo de Jesus (Lisboa) Carlos Boavida

1815 Adereços de vidro, dos séculos XVI-XVIII, procedentes do antigo Convento de Santana de Lisboa (anéis, braceletes e contas)

Joana Gonçalves / Rosa Varela Gomes / Mário Varela Gomes

1837 Da ostentação, luxo e poder à simplicidade do uso quotidiano: arqueologia e simbologia de joias e adornos da Idade Moderna Portuguesa Jéssica Iglésias

1849 Os amuletos em Portugal - dos objetos às superstições: o coral vermelho Alexandra Vieira

1865 Cerâmicas de Vila Franca de Xira nos séculos XV e XVI Eva Pires

1879 «Não passa por teu o que me pertence». Marcas de individualização associadas a faianças do Convento de Nossa Senhora de Aracoeli, Alcácer do Sal Catarina Parreira / Íris Fragoso / Miguel Martins de Sousa

1891 Cerâmica de Leiria: alguns focos de produção

Jaqueline Pereira / André Donas-Botto

1901 Os Fornos na Rua da Biquinha, em Óbidos Hugo Silva / Filipe Oliveira

1909 A casa de Pêro Fernandes, contador dos contos de D. Manuel I: o sítio arqueológico da Silha do Alferes, Seixal (século XVI) Mariana Nunes Ferreira

1921 O Alto da Vigia (Sintra) e a vigilância e defesa da costa Alexandre Gonçalves / Sandra Santos

1937 O contexto da torre sineira da Igreja de Santa Maria de Loures Paulo Calaveira / Martim Lopes

1949 A Necrópole do Hospital Militar do Castelo de São Jorge e as práticas funerárias na Lisboa de Época Moderna Susana Henriques / Liliana Matias de Carvalho / Ana Amarante / Sofia N. Wasterlain

1963 SAND - Sarilhos Grandes Entre dois Mundos: o adro da Igreja e a Paleobiologia dos ossos humanos recuperados

Paula Alves Pereira / Roger Lee Jesus / Bruno M. Magalhães

1975 Expansão urbana da vila de Cascais no século XVII e XVIII: a intervenção arqueológica na Rua da Vitória no 15 a 17

Tiago Pereira / Vanessa Filipe

1987 Novos dados para o conhecimento do Urbanismo de Faro em época Moderna Ana Rosa 
1995 Um exemplo de Arqueologia Urbana em Alcoutim: o Antigo Edifício dos CTT Marco Fernandes / Marta Dias / Alexandra Gradim / Virgílio Lopes / Susana Gómez Martínez

2007 Palácio dos Ferrazes (Rua das Flores/Rua da Vitória, Porto): a cocheira de Domingos Oliveira Maia

Francisco Raimundo

2021 As muitas vidas de um edifício urbano: História, Arqueologia e Antropologia no antigo Recreatório Paroquial de Penafiel Helena Bernardo / Jorge Sampaio / Marta Borges

2035 O convento de Nossa Senhora da Esperança de Ponta Delgada: o contributo da arqueologia para o conhecimento de um monumento identitário João Gonçalves Araújo / N’Zinga Oliveira

2047 Arqueologia na ilha do Corvo... em busca da capela de Nossa Senhora do Rosário Tânia Manuel Casimiro / José Luís Neto / Luís Borges / Pedro Parreira

2059 Perdidos à vista da Costa. Trabalhos arqueológicos subaquáticos na Barra do Tejo Jorge Freire / José Bettencourt / Augusto Salgado

2071 Arqueologia marítima em Cabo Verde: enquadramento e primeiros resultados do projecto CONCHA

José Bettencourt / Adilson Dias / Carlos Lima / Christelle Chouzenoux / Cristóvão Fonseca / Dúnia Pereira / Gonçalo Lopes / Inês Coelho / Jaylson Monteiro / José Lima / Maria Eugénia Alves / Patrícia Carvalho / Tiago Silva

2085 Trabalhos arqueológicos na Cidade Velha (Ribeira Grande de Santiago, Cabo Verde): reflexões sobre um projecto de investigação e divulgação patrimonial André Teixeira / Jaylson Monteiro / Mariana Mateus / Nireide Tavares / Cristovão Fonseca / Gonçalo C. Lopes / Joana Bento Torres / Dúnia Pereira / André Bargão / Aurélie Mayer / Bruno Zélie / Carlos Lima / Christelle Chouzenoux / Inês Henriques / Inês Pinto Coelho / José Lima / Patrícia Carvalho / Tiago Silva

2103 A antiga fortificação de Quelba / Khor Kalba (E.A.U.). Resultados de quatro campanhas de escavações, problemáticas e perspectivas futuras Rui Carita / Rosa Varela Gomes / Mário Varela Gomes / Kamyar Kamyad

2123 Colónias para homens novos: arqueologia da colonização agrária fascista no noroeste ibérico Xurxo Ayán Vila / José Mạ . Señorán Martín 


\title{
O NORDESTE TRANSMONTANO NOS ALVORES DA IDADE MÉDIA. NOTAS PARA REFLEXÃO
}

\author{
Ana Maria da Costa Oliveira ${ }^{1}$
}

\begin{abstract}
RESUMO
Compreender a fronteira do nordeste transmontano, a sua defesa e dinâmica no contexto da formação do reino de Portugal, requer uma apreensão da ocupação territorial cuja génese mergulha em períodos ancestrais. As estratégias e opções de fixação de comunidades ao longo dos séculos, obedecendo a diferentes condicionalismos e oportunidades, desenharam um cenário que viria a enquadrar, com todas as suas dificuldades e vicissitudes, uma política de autonomia em relação ao território leonês/castelhano.

O desequilíbrio patente no conhecimento que tem sido produzido sobre estes períodos ancestrais, suscita questões inevitáveis sobretudo sobre a ausência de materialidades para o período alto medieval nesta região. Foi este silêncio que suscitou uma análise crítica dos dados conhecidos, propondo abordagens diversificadas que podem trazer alguma objetividade.

Palavras-chave: Trás-os-Montes, Alta Idade Média, Povoamento, Revisão.
\end{abstract}

\begin{abstract}
To understand the border of the northeastern region of Trás-os-Montes, it's defense system and dynamics in the context of the Portuguese Kingdom formation, requires a knwoledge of the territorial ocupation whose genisis dive in ancestral periods.

The strategies and settlement options of the population over the centuries, obeyed different conditions and opportunities and draw a scenario that would come to frame, with all its difficulties and vicissitudes, the autonomic policy in relation to the Leonese / Castilian territory.

The imbalance in the knowledge that has been produced about these ancestral periods, namely the absence of information about the early medieval period in this region, raised some questions and gave rise to a critical analysis of the known data, leading to the proposal of diversified approaches and new perspecives.
\end{abstract}

Keywords: Trás-os-Montes, High Medieval Age, Settlement, Data review.

\section{INTRODUÇÃO}

No âmbito do nosso projeto de Doutoramento em Estudos do Património - Arqueologia, intitulado "Os castelos e a fronteira entre Vinhais e Miranda do Douro (séculos XI-XVI): estratégias e diálogos na raia transmontana", que estamos a desenvolver na Faculdade de Letras da Universidade do Porto, temos vindo a estudar a região nordeste transmontana, entre os concelhos de Vinhais e Miranda do Douro, área que, efetivamente, se tornou de fronteira a partir do tratado de Alcañices, datado de 1297.
A nossa atenção, neste texto, centrar-se-á num período anterior a esse momento, mais concretamente, no espaço histórico que sucede a "desarticulação" da organização romana e inicia uma reorganização muçulmana, com início em 711 . Interessa perceber a evolução de um território que acabará por entrar na esfera da monarquia asturo-leonesa, identificando as diferentes soluções que formaram as estruturas de povoamento. Estas comunidades vão ser o suporte dessa monarquia que, com o apoio de uma nobreza em ascensão, enquadrará um território em expansão. Da conjugação deste processo político e

1. Arqueóloga, Bolseira de Doutoramento da FCT SFRH/BD/129436/2017, investigadora do CITCEM; anamcostaoliveira@gmail.com 
militar e desta rede de povoamento resultará, mais tarde, o desenho de novas fronteiras.

Desta época alto-mediévica, nomeadamente nesta faixa transmontana, pouco se sabe. As fontes documentais são praticamente inexistentes e os trabalhos arqueológicos realizados são insuficientes, fornecendo uma leitura parcelar e incaracterística da realidade. Este silêncio e desconhecimento, compromete em parte a compreensão das fases cronológicas posteriores que levaram à formação da fronteira transmontana. Desta forma, sentimos a necessidade de dedicar parte da nossa análise e reflexão aos possíveis modelos de ocupação territorial dos alvores da idade média.

O que propomos são, pois, reflexões e possibilidades, ainda em desenvolvimento, que dão conta de uma realidade diversificada, muito dependente das características territoriais de cada região, constituindo possíveis soluções diferenciadas de ocupação, exploração e circulação.

Os dados recolhidos configuram uma amostragem generalista que pretende, num primeiro momento, lançar o debate e suscitar na comunidade científica o interesse na realização de estudos mais aprofundados, complementados com planos de trabalhos arqueológicos, que permitam lançar alguma luz sobre as mudanças ocorridas durante a alta idade média.

\section{METODOLOGIA}

A análise do povoamento alto medieval que se propõe abrange três dos quatro concelhos estudados no âmbito do doutoramento: Bragança, Vimioso e Miranda do Douro. O concelho de Vinhais, que completa o território da fronteira nordeste de Trás-os-Montes, não integra esta análise porque à data da redação deste texto, o trabalho de pesquisa não se encontra concluído.

O trabalho realizado teve como base os dados recolhidos na bibliografia. Para a região transmontana contam-se algumas monografias ${ }^{2}$ que, variando na sua abrangência e pertinência, têm servido de suporte a investigações e trabalhos mais recentes. Tendo em conta a limitação de espaço de publica-

2. De entre os diversos títulos, não podemos deixar de realçar o incontornável Abade de Baçal e as suas Memórias Arqueológico-Históricas do Distrito de Bragança. Edição da Câmara Municipal de Bragança / Instituto Português de Museus - Museu do Abade de Baçal. Tomo I - XII. ção, limitar-nos-emos a referir duas fontes obrigatórias: o Portal do Arqueólogo 3 (PA) e o estudo de Francisco Sande Lemos (1993), que serve de base ao portal do património arqueológico e a outros estudos posteriores ${ }^{4}$.

Selecionados os sítios e ocorrências que julgamos pertinentes, passamos ao trabalho de contextualização e caracterização dos dados, através de visitas e representação cartográfica. A análise e cruzamento destes resultados, com os raros trabalhos de escavação arqueológica que se têm realizado em sítios de ocupação tardo-antiga na região e em outras regiões periféricas, nomeadamente no país vizinho, suscitaram um conjunto de reflexões e possibilidades que pensamos dever ser consideradas em pesquisas posteriores.

\section{TERRITÓRIO}

Como base de trabalho optamos pelo território organizado segundo as atuais divisões administrativas por não se conhecerem, a nível regional, outras divisões para as épocas em estudo.

Os três concelhos estudados, somam um território de cerca de $2.116 \mathrm{~km}^{2}$ sendo Bragança o mais vasto. Em termos geográficos, cabe realçar que uma parte substancial do território é ocupado por elevações, das quais se destacam as serras da Nogueira e de Montesinho, ambas no concelho de Bragança. Para além das serras, importa realçar os planaltos - pontuados por cabeços cuja altitude máxima oscila entre os $600-800 \mathrm{~m}$, estendendo-se de norte para sul, ocupando sobretudo a região inferior do território. Entre estes planaltos cabe destacar o de Izeda, que se prolonga para Macedo de Cavaleiros; o de Milhão-Argozelo; e o extenso planalto de Miranda do Douro. A norte destaca-se a depressão de Bragança e o vale que, vindo de oeste, dá acesso à cidade. Nesta faixa foi aberto o IP4 e, posteriormente, a autoestrada $\mathrm{A}_{4}$.

Em regra, os planaltos têm a delimitá-los linhas de água que, grosso modo, correm de norte para sul.

\footnotetext{
3. Disponível em: https://arqueologia.patrimoniocultural.pt.

4. O mais recente é a monografia coordenada por Fernando de Sousa, com o título "Bragança. Das origens à Revolução Liberal de 1820", editada pela Câmara Municipal de Bragança e o CEPESE - Centro de Estudos da População, Economia e Sociedade, em 2019.
} 
Assim, o planalto de Izeda é cortado e delimitado a leste pelo rio Sabor; o rio Maçãs delimita a leste o planalto de Milhão-Argozelo, definindo parcialmente a linha de fronteira entre Portugal e Espanha; e o planalto de Miranda do Douro é delimitado a oeste pelo rio Angueira e a leste pelo rio Douro, marcador de fronteira internacional. Mais a norte, destaca-se ainda o rio Fervença, que atravessa a cidade de Bragança e é tributário do Sabor e o rio Rabaçal que corre na extremidade oeste de Bragança e é tributário do rio Tuela. É neste vasto e complexo território que tentaremos inferir a génese da ocupação medieval.

\section{DADOS}

Durante a nossa investigação identificamos 193 ocorrências passiveis de análise e reflexão (Mapa 1). Este conjunto, muito pouco homogéneo e preciso, distribui-se no território da seguinte forma: 44 ocorrências no território atual de Miranda do Douro, 26 no de Vimioso e 123 no de Bragança. (Gráfico 1) Com base nas propostas cronológicas apontadas pelas fontes bibliográficas, verificamos que os vestígios da ocupação da Idade do Ferro (Mapa 2) e de Época Romana (Mapa 3) são bem mais expressivos. Verifica-se uma quebra bastante acentuada para os indícios da Alta Idade Média (Mapa 4) e um tímido crescimento para o longo período da Idade Média. Claro que estes dados não traduzem "a realidade", são antes o resultado dos trabalhos realizados até aos dias de hoje. Paralelamente, dizem respeito a um período cronológico muito longo, cujo conhecimento das materialidades não se traduz de forma igual e equitativa. Correspondem, portanto, a diferentes realidades que se traduziram em diferentes soluções, havendo, como é evidente, pontos de contato na transição entre cada uma delas, dificultando assim uma leitura objetiva.

Contudo, e mesmo considerando todas as reservas, não deixa de ser curiosa a discrepância de ocorrências para os períodos alto-medievais. O que significará esta constatação?

\section{ANÁLISE}

As 193 ocorrências foram divididas por tipologias de sítio, podendo o mesmo sítio ter mais do que uma ocorrência - por exemplo, um povoado poderá incluir as estruturas de habitação, uma igreja e ne- crópole. Cada uma destas estruturas pode ou não ser contemporâneas. Nestes casos, e para a atual análise, apenas consideramos a ocorrência que nos parece poder revelar uma ocupação da Alta Idade Média, deixando a análise do conjunto para outra altura. Temos consciência que a tipificação e enquadramento cronológico de determinados sítios, fundamentados em dados exclusivamente de superfície, é uma opção limitadora, logo discutível, dificilmente reveladora de uma realidade completa. Mesmo assim, aceitamos o risco apenas como ponto de partida.

Convém ainda esclarecer que, quando não nos foi possível acrescentar novos dados sobre determinado sítio, para além daqueles que colhemos na bibliografia conhecida, optamos por atribuir a tipologia e cronologia sugerida pelas fontes consultadas. Contudo, quando analisamos o sítio, estudamos a sua morfologia e o contextualizamos no território, consideramos, se for o caso, outras possibilidades para a sua ocupação/utilização, por vezes, enquadráveis no período cronológico sobre o qual nos detemos aqui.

Centremos agora a nossa atenção nos locais de assentamento, claramente maioritários, nomeadamente, nos povoados fortificados, povoações - abertas ou em altura e sem muralhas - e nos pequenos habitats. Estes sítios totalizam 126 estações, o equivalente a $65,2 \%$ do total dos assentamentos. Deste total, o grupo mais numeroso é o dos povoados fortificados, com 70 sítios; seguem-se as povoações com 39 ocorrências; e os habitats com 17 estações.

\subsection{Povoados fortificados}

Do total dos 70 povoados fortificados identificados, 39 foram classificados com cronologias exclusivamente da Idade do Ferro, o que corresponde a 55,7\% do total. Se considerarmos os povoados cuja cronologia inicia nesta época e que têm uma ocupação posterior, o número sobe para 59. Assim, podemos inferir que, dos 70 povoados fortificados datados da Idade do Ferro, 20 tiveram uma ocupação diacrónica, sendo que, apenas três, têm uma possível ocupação durante a Alta Idade Média: Castelo Velho, em Campo de Víboras (Vimioso); Cabeço da Cocolha, Angueira (Vimioso); e São João das Arribas (Miranda do Douro).

Objetivamente, apenas no povoado fortificado de São João das Arribas está confirmada uma ocupação alto-medieval, graças às campanhas arqueológicas 
que têm vindo a ser desenvolvidas nos últimos anos. Aliás, os resultados têm demonstrado ténues indícios da Idade do Ferro, sendo mais evidentes os vestígios romanos e, sobretudo, da Alta Idade Média. Análises radiocarbónicas apresentaram uma cronologia para estratos do interior do castro datáveis dos séculos VI e VII. Nos terraços das imediações foram identificadas datações entre os séculos IV e XVII. Apesar de ser considerado na bibliografia como um povoado da Idade do Ferro (Sande Lemos e PA, entre outros), os trabalhos arqueológicos têm aclarado uma outra realidade. São os próprios responsáveis pelas escavações arqueológicas que sugerem "colocar em debate a existência de um castro nos termos em que a historiografia tradicional defende desde cedo." Acrescentam que, apesar de terem encontrado "materiais mais antigos do que o Baixo Império", não registaram "vestígios estruturais organizados" da mesma época. Significativo é "o material cerâmico de importação" que revela "um vigor comercial aparentemente extraordinário para esta zona do Douro. Ao longo das últimas campanhas foram descobertos fragmentos de sigillata clara $\mathrm{D}$, oriundas do Norte de África, materiais do Vale do Ebro e da Rioja e mesmo importações regionais, oriundas de Bracara Augusta e de Conímbriga." Paralelamente aos vestígios romanos foram registados nos promontórios junto ao castro "manchas de materiais, aparentemente da Alta Idade Média, que revelam uma ocupação mais extensa do que a que a historiografia tradicional sugere.” (Pereira \& Salgado, 2018, pp. 131-132).

Para além dos povoados fortificados com origem pré-histórica, registam-se dois com possível fundação romana: o povoado da Senhora da Hera, Espinhosela (Bragança), que também tem confirmada ocupação medieval, e o povoado do Castrolouço, Atenor (Miranda do Douro). Sobre este último, Sande Lemos diz que a muralha poderia ser tardia, da Alta Idade Média, apesar de o considerar romano (1993, pp. 211-213).

Notamos ainda que se registam sete povoados com cronologia indeterminada o que aumenta o campo das possibilidades para outras ocupações alto-medievais. Na verdade, pensamos que alguns dos povoados considerados apenas da Idade do Ferro merecem uma revisão cuidada, pois as suas características morfológicas e posicionamento estratégico, sugerem o uso do espaço nesta época conturbada, quer por razões de defesa, de controlo territorial ou de vigia 5 .

\subsection{Povoados abertos}

Este grupo contabiliza 39 povoados, sendo os de cronologia romana e medieval em número de nove. Os povoados com possível cronologia da Alta Idade Média são sete e, à exceção de um, todos têm ocupação a iniciar em Época Romana e apenas quatro continuam ocupados na Idade Média.

Atentando nos povoados com ocupação da Alta Idade Média, comecemos pelo que tem como cronologia mais recuada a Idade do Ferro. Trata-se do povoado de Castelar ou Castro de Picote (Miranda do Douro), considerado pelo PA como povoado fortificado, mas que não apresenta um sistema defensivo evidente ${ }^{6}$. A última intervenção arqueológica neste sítio ocorreu em 2013, no âmbito do Projeto de Investigação: História do Povoamento de Picote, promovido pela Frauga - Associação para o Desenvolvimento Integrado de Picote e pelo Departamento de Ciências e Técnicas do Património da Faculdade de Letras da Universidade do Porto. Os trabalhos não foram de todo conclusivos, mas confirmaram materiais arqueológicos com uma larga diacronia Bronze Final até Época Medieval - e estruturas pétreas que formavam um sistema de socalcos, cuja funcionalidade não foi aferida.

Os povoados cuja cronologia inicia em Época Romana, e que segundo a bibliografia terão tido ocupação alto medieval, são dois: Castro de Coelhoso e Trás do Souto, ambos em Bragança. A estes, propomos que se junte o povoado das Faceiras da Granja, em Duas Igrejas (Miranda do Douro), que a bibliografia diz ser romano, mas onde foram identificados materiais tardo-antigos. Nas proximidades, registaram-

\footnotetext{
5. Dentro desta possibilidade consideramos os seguintes povoados: Cabeço do Cercado; Crasto; Cabecinho dos Mouros; Sumidago; Castanheiro do Senhor; Picoto; Fragas do Castro; Castragosa; Castro da Sapeira; Fragas do Castro; Cercas; Alto do Castro e Castelo das Olgas.

6. Sande Lemos admite que a fundação deste sítio é problemática, desvalorizando o registo de alguma cerâmica manual. Considera que este povoado não é um povoado fortificado e que terá sido fundado por volta do século I d.C. (1993, pp. 236-237). O PA considera este sítio como um povoado fortificado, com base num muro que forma um patamar agrícola, colocando como hipótese o desmantelamento da muralha.
} 
-se dois núcleos sepulcrais. O da Fonte do Amador será, segundo Sande Lemos, de cronologia alto medieval, com reaproveitamento de estelas funerárias romanas (1993, pp. 218-219). Cremos que a probabilidade de existir aqui, ou nas imediações, um povoado da Alta Idade Média é considerável. Todos estes povoados se situariam próximos de zonas de cultivo. Na zona do Castro de Coelhoso está identificada exploração mineira e a cerca de $3 \mathrm{~km}$ a nascente das Faceiras da Granja, em Miranda do Douro, passava a via designada de Carril Mourisco.

Ainda como povoados abertos, apesar de serem considerados fortificados, e com ocupação que medeia entre Época Romana e a Idade Média, contam-se três. Para os povoados da Coroa (Miranda do Douro) e para o de São Martinho, em Algoso (Vimioso), não são concretizadas cronologias alto medievais, contudo, e à semelhança do caso das Faceiras da Granja, os indícios, nomeadamente terra sigillata tardia e sepulturas estruturadas com lajes, atribuídas a cronologias medievais, nomeadamente em São Martinho (Lemos, 1993, p. 411), leva-nos a propor uma continuidade de ocupação entre Época Romana e plena Idade Média.

Com cronologias da Alta Idade Média e comprovadas por análises radiocarbónicas, regista-se o povoado de Torre Velha de Castro de Avelãs (Bragança). O PA designa este sítio como povoado fortificado. Contudo coloca interrogações, pois não se detetou nenhuma estrutura defensiva, facto que corroboramos depois de uma visita ao local. Nos anos de 2012 e 2013 desenvolveu-se um projeto arqueológico conjunto entre a Câmara Municipal de Bragança e a Universidade de Coimbra. A "Intervenção arqueológica no sítio da Torre Velha, Terras de S. Sebastião, Bragança”, foi da responsabilidade da arqueóloga Maria Clara Machaqueiro André (Câmara Municipal de Bragança) e de Pedro Jorge Cardoso de Carvalho (Universidade de Coimbra) e contou com a colaboração de Miguel Cipriano Esteves Costa e Sofia Catarina Gabriel Tereso. Os resultados revelaram "uma importante ocupação romana (século I-V d.C.)" e "vestígios do período suevo-visigótico", bem como, dos séculos "que antecederam a formação do reino de Portugal.” (PA).

\subsection{Habitats}

Em número de 17 são os designados habitats, que correspondem a pequenas quintas, casais, etc.. Nes- te grupo, destacam-se as ocorrências de Época Romana, contando-se apenas o sítio de São Martinho de Carrazedo com cronologia provável da Alta Idade Média. Segundo Sande Lemos, existiriam neste sítio as ruínas de "um edifício que terá sido uma capela de evocação a S. Martinho” (1993, p. 6o). Embora não tenhamos visitado o local, coberto por densa vegetação, há notícias de telhas e outros materiais de construção.

Ainda no que concerne aos habitats, devemos notar que existem duas ocorrências de cronologia indeterminada, nomeadamente o Lombo da Igreja, em Rebordaínhos, e Izei, Nogueira, ambos em Bragança. Atentemos no sítio do Lombo da Igreja, que poderá ter correspondido, no nosso entender, a um povoado em altura e não a uma pequena quinta. Aquando da nossa visita, constatamos materiais arqueológicos, não só neste local, mas espalhados por uma área mais extensa. O sítio ocupa um lombo aplanado com altitudes superiores a $1000 \mathrm{~m}$, com solos agrícolas, atualmente ocupados com soutos, e com um excelente domínio territorial. Apesar de não termos detetado estruturas, observamos que nos terrenos lavrados existe alguma pedra, podendo indiciar antigas construções e buracos de poste, nas zonas onde o penedo aflora. Segundo o PA, a tradição local diz "que aqui teria sido a primitiva igreja e povoação de Rebordainhos, antes de se mudar para baixo."

Dentro dos materiais observados, contam-se telha de meia cana, cerâmica comum e metais, cujas cronologias poderão enquadrar-se em período medieval. Para além do habitat, detetamos ainda num cabeço granítico que ocupa, sensivelmente, o centro do lombeiro, grande número de buracos de poste e entalhes que sugerem uma possível estrutura que julgamos poder ter correspondido a uma atalaia ou torre de vigia.

\subsection{Necrópoles}

Das 24 necrópoles registadas, apenas uma éindicada com possível cronologia da Alta Idade Média: Fonte Amador (Miranda do Douro). Contudo, cabe destacar a necrópole do povoado de Torre Velha de Castro de Avelãs, objeto de intervenções arqueológicas e de análises radiocarbónicas, como já referimos acima. Segundo os responsáveis pelos trabalhos arqueológicos, foram registadas 43 sepulturas, e escavadas 34. Exumaram-se 21 indivíduos não havendo registo de espólio associado (Tereso \& alii, 2015, p. 149). 
As datações revelaram uma fase mais antiga de enterramentos, com cronologias dos séculos VI-VIII, e uma outra fase com cronologias dos séculos X-XII. Destacamos ainda a necrópole de São João, localizada na cidade de Bragança, a menos de $200 \mathrm{~m}$ das muralhas da cidadela, associada à desaparecida igreja paroquial de São João, referida nas inquirições de 1258. A sua escavação arqueológica, realizada no âmbito dos trabalhos de requalificação da Polis, em 2003, revelou alguns elementos de interesse sobre os quais importa refletir. Na Travessa de São João, foi escavada "uma sepultura de inumação infantil, escavada na rocha, com lajes de xisto à cabeceira, parte torácica e abdominal." Por baixo desta sepultura foi registado "um buraco circular, escavado também na rocha em xisto, onde se detectaram cinco peças cerâmicas características da época baixo-medieval (séculos XIII e XIV) com enchimento de vários tipos de sedimentos: carvões, cinzas e ossos de animais." (Capela \& alii, 2004, p. 62).

$\mathrm{Na}$ restante necrópole foram ainda recolhidos "um anel e um par de brincos de prata." O conjunto total dos materiais permitiram aos investigadores sugerir que "a necrópole poderá datar da fundação da Igreja de S. João, no séc. XIII e prolonga-se até ao séc. XVIII." (Capela \& alii, 2004, pp. 62-63). Uma ampla diacronia, portanto.

Resumindo, os autores sintetizam que nesta Travessa foram identificadas "duas fases sepulcrais: uma moderna caracterizada pelas sepulturas em fossa simples escavadas num nível sedimentar e outra de época medieval com lajes de xisto e escavadas parcialmente na rocha de base." (Capela \& alii, 2004, p. 62).

Estas evidências merecem um apontamento, nomeadamente sobre as cronologias apresentadas. Ao que tudo indica não foram realizadas análise para determinar datações para as diferentes fases de enterramento. A proposta avançada pelos investigadores é sustentada na altura provável da construção da igreja de São João (séc. XIII), na tipologia dos sepulcros, nas relações estratigráficas e nos materiais recolhidos, realçando-se os objetos de adorno pessoal, encontrados em duas sepulturas distintas, e no conjunto cerâmico da fossa subcircular. Ora estes indícios, por si só, parecem-nos insuficientes e, de certa forma, equívocos, pois seria importante esclarecer a tipologia dos adornos encontrados e apresentar os paralelos para o conjunto cerâmico da fossa.

\section{REFLEXÃO}

Apresentados alguns dos dados recolhidos, torna-se necessário questionar a escassez de vestígios de uma ocupação alto-medieval na região nordeste transmontana. A insuficiência de trabalhos arqueológicos não justifica, por si só, esta realidade, pois a mesma falta é sintomática para ocupações de outras cronologias. Mesmo admitindo um recuo demográfico em época alto-medieval, causa-nos estranheza a acentuada ausência de vestígios, quando, nos sítios intervencionados, se verifica uma certa vitalidade cultural para este período, como no caso de Torre Velha de Castro de Avelãs e de São João das Arribas. Por outro lado, não podemos deixar de notar que os trabalhos de prospeção que antecederam as escavações nestes últimos dois sítios, conferiram-lhes cronologias essencialmente da Idade do Ferro, facto de certa forma contrariado pelos trabalhos de escavação e pelas datações radiocarbónicas. Ora, esta recontextualização de determinados assentamentos humanos alerta para uma necessária revisão de critérios de análise e interpretação dos sítios de povoamento alto-medievais. Parece evidente que os resultados de prospeções "básicas", focadas apenas, e só, nos vestígios materiais identificáveis à superfície e na bibliografia existente, resultam em leituras ambíguas que não permitem "constituir uma narrativa histórica, com características concretas e com propostas crono-temporais seguras." (Bohigas Roldán, 1999, p. 93). A arqueologia medieval, especialmente a que se dedica a cronologias mais antigas, tem sido prejudicada por determinados condicionalismos. Por um lado, pela prevalência de uma "arqueologia preventiva ou de gestão" que impede, frequentemente, um trabalho e uma investigação aprofundados; por outro lado, o desinvestimento na formação "ligadas a este período cronológico", que resulta na falta de investigadores experientes e capazes de identificarem "vestígios importantes para a compreensão do povoamento e do território medieval." (Bohigas Roldán, 1999, p. 8o-81).

Felizmente, e para a região transmontana, têm-se desenvolvidos alguns trabalhos de monta, nomeadamente os realizados no âmbito da construção das barragens de Foz Tua ou a do Sistema Hidroelétrico do Baixo Sabor, que contaram com importantes escavações arqueológicas, algumas com datações radiocarbónicas. Contudo, estamos longe de um corpus de trabalhos, cujos dados possibilitem uma 
sistematização e caracterização da ocupação humana medieval em Trás-os-Montes. Falta um planeamento teórico e conceptual para a arqueologia medieval, que tenha por base projetos de investigação integrados, permitindo leituras globais que incorporem os diferentes elementos estruturadores do território. Passar de uma leitura iminentemente descritiva, para uma análise interpretativa e procurar resultados mais objetivos e menos tipológicos ${ }^{7}$.

$\mathrm{Na}$ verdade, e ao longo deste estudo, verificamos que houve uma variedade considerável de opções de assentamento que, adaptando realidades já existentes ou criando novas soluções, desenharam um quadro de povoamento que não se resume a uma única solução. Esta variabilidade é comum para outras regiões estudadas, quer em Trás-os-Montes, quer no país vizinho, nomeadamente na região de Zamora ${ }^{8}$. Durante a Alta Idade Média, e no que se refere à região do nordeste transmontano, as populações não terão ocupado unicamente povoados fortificados, como São João das Arribas, em Miranda do Douro, ou povoados "abertos" em altura, como Torre Velha de Castro de Avelãs, em Bragança. Cremos existirem indícios de pequenas comunidades rurais, implantadas em locais abrigados, longe o suficiente das principais vias de comunicação, herdadas da romanização, e próximas das zonas de cultivo, que tanto poderiam ocupar terraços, como na Capela de São Paulo, em Miranda do Douro, como parcelas agrícolas antigas que se estenderiam pelos rebordos dos planaltos, muitas vezes, junto a desaparecidas ocupações romanas, como em Faceiras da Granja,

7. Seguindo esta linha de investigação, foram dados importantes passos, nomeadamente através do projeto "As sepulturas escavadas na rocha do norte de Portugal e Vale do Douro (SER-NPVD)", da responsabilidade científica do Prof. Doutor Mário Jorge Barroca e promovido pelo CITCEM - Centro de Investigação Transdisciplinar «Cultura, Espaço e Memória» e Faculdade de Letras do Porto. Este projeto, no qual colaboramos, procura reunir e sistematizar toda a informação disponível sobre sepulturas escavadas na rocha no norte de Portugal, relacionando-as com as diferentes estruturas territoriais. Foi criada uma base de dados, disponível online, que pretende contributos vários, garantindo uma constante atualização dos dados. A apresentação do projeto disponível em: https://www.citcem. org/projeto/36.

8. Para o território português e no que concerne à zona transmontana ver Tente, Catarina, 2017, pp. 4-57. Para o território zamorano ver Gutiérrez González, 2017, pp. 1985 ou Martín Viso, 2001, pp. 75-122. em Duas Igrejas (Miranda do Douro). Também parece terem existido comunidades pastoris implantadas em vales ou nas faldas das montanhas, junto a cursos de águas secundários, com lameiros para a criação de gado bovino, como em São Martinho, Carrazedo (Bragança).

A tradição conserva ainda uma memória toponímica de lugares onde terão existido antigas comunidades, muitas vezes associadas a igrejas e a sepulturas, estas quase sempre estruturadas por lajes, e, por vezes, próximas de locais fortificados: como São Martinho, em Algoso, onde Sande Lemos diz poder existir uma fortificação da Alta Idade Média no Cabeço da Forca (1993, pp. 411-412).

Igualmente importantes, e pouco conhecidos nesta região, são os centros militares e de poder que, apesar da desestruturação que se seguiu ao período romano, terão tido alguma espécie de materialização, indispensável para uma certa estruturação territorial, que, mais tarde servirão os propósitos dos avanços da monarquia asturo-leonêsa dos inícios da Idade Média. Estes sítios, habitados ou não, privilegiariam critérios estratégicos de controlo e vigia territorial. Apoiados em comunidades fortes e de importância relevante, como poderia ser o caso de Torre Velha de Castro de Avelãs, ou talvez de Bragança ${ }^{9}$, existiria uma rede de estruturas militares e administrativas necessárias à manutenção da paz ou defesa das populações. Estas estruturas, num território imenso e parco de população, poderão ter-se materializado em antigos povoados fortificados, cuja evidente importância geoestratégica não teria sido ignorada: seria o caso do Castelo de Pinela, em Bragança. Este sítio, para o qual a bibliografia não refere especificamente uma cronologia alto medieval, ergue-se no planalto de Parada, controlando grande parte do território bragançano. Tem um domínio abrangente sobre o vale que acede à cidade de Bragança, vindo de sudoeste, e comunica visualmente com grande parte dos locais fortificados das imediações. Pela sua dimensão e pelos materiais espalhados à superfície, foi claramente habitado em diferentes épocas

9. Notamos que no Paroquial Suevo é mencionado o pagus Brigantia e apesar de se desconhecer o sítio exato desta paróquia, não se poderá descartar a hipótese de ela corresponder à zona onde se ergue hoje a cidade de Bragança. Mais tarde, em 1194, D. Sancho I irá adquirir, talvez no mesmo sítio, a herdade de Benquerença e em 1188, deixa uma quantia de dinheiro para fortificar a cidade (DS, p. 118-119, Doc. 76 e DS, p. 49-51, Doc. 31). 
cronológicas, sendo ainda referido na documentação do século XIII ${ }^{10}$. É provável, portanto, que o Castelo de Pinela tenha tido um importante papel como centro estruturador do território em épocas alto medievais, podendo mesmo ter continuando "como cabeça da "terra" de Bragança", antes da vila, com o mesmo nome, ter assumido esse papel (Gomes, 2003, p. 11).

Num território acidentado e com um coberto florestal certamente diferente, onde os eixos de circulação mais importantes não seriam propriamente numerosos, a circulação pelos vales dos rios ou pelos planaltos seriam pontos de necessário controlo e vigilância. Ao percorrer o território apercebemo-nos que os antigos povoados edificados em cabeços, na zona planáltica, ou junto a pequenos cursos de água, ou erguidos em esporões e meandros dos rios Sabor, Angueira, Maçãs, etc., eram locais privilegiados para vigiar a circulação de pessoas e bens.

Esta rede de estruturas parece obedecer a diferentes níveis de controlo territorial: o local, formado através de estruturas fortificadas, por vezes reaproveitadas de construções pré-existentes, que vigiariam as produções agrícolas, de pastoreio, ou de mineração, como poderia ser o caso de Castrilhão de Coelhoso ${ }^{11}$, Bragança; o regional, que controlaria as zonas de passagem, por exemplo, vales agrícolas e de pastoreio, utilizando pontos estratégicos de médio alcance, como esporões ou meandros, que possibilitam uma visualização parcelar de um curso de água, ou de passagens a vau de rios e ribeiras, como no caso de Penedo, Grijó de Parada, ou Fragas do Castro, em São Julião de Palácios, ambos em Bragança - o primeiro sobre o rio Sabor e o segundo sobre o

10. Nas inquirições de 1258, o castelo de Pinela, também conhecido por Alfenim e Alvelina é mencionado no Julgado de Lamas de Orelhão, na paróquia de Santo Estevão de Fresulfe, afirmando as testemunhas que a vila de Parada foi regalenga e que D. Sancho I a doou a "Donno Galeco", pai de "Munio Pelagij milite de Trasbaceiro", pelo castelo de "Aluelia" que "Donno Galeco" construiu. É referido ainda, nas inquirições no Julgado de Bragança, na paróquia de Santa Maria de Serapicos, afirmando-se que os homens da vila de "Paradias" entregavam o foro aos homens do rei que estavam em "Alueliam” (PMH - Inq. 1258).

11. O PA aponta para este sítio uma ocupação da Idade do Ferro. Já Sande Lemos diz que o Castrilhão terá sido romanizado (1993, pp. 70-71). Pensamos que, pela sua posição geoestratégica, de controlo de uma região mineira, poderá também ter sido utilizado como estrutura defensiva/vigia durante períodos alto-medievais e medievais. rio Maçãas ${ }^{12}$; e os pontos de controlo suprarregionais, articulados com outros pontos regionais, privilegiando um controlo geoestratégico mais vasto, vigiando as grandes movimentações e quase sempre em articulação com centros estruturadores de poder como seria o Castelo de Pinela. Neste grupo, deverá destacar-se o sítio da Senhora da Conceição, Carocedo, Faílde, e a Fraga do Cavaleiro, também em Faílde, ambos no rebordo sudeste do vale que conduz a Bragança, tratando-se de povoados fortificados com origens anteriores à Alta Idade Média; no rebordo oposto, e comunicando visualmente com os sítios anteriores, podemos destacar o Castelo ${ }^{13}$, em Quintela de Lampaças, a possível atalaia do Lombo da Igreja, em Rebordaínhos, e o Castelo de Rebordãos ${ }^{14}$. Todos estes sítios ocupam as faldas da serra da Nogueira. O Castelo seria um povoado fortificado, com uma forte implantação territorial, e de cronologias indeterminadas. O Lombo da Igreja, um povoado "aberto" em altura, onde se destaca um cabeço rochoso com buracos de poste, sugerindo a existência de uma possível construção perecível, talvez uma torre ou plataforma elevada, com claro domínio sobre o vale. Sobre a cronologia do povoado nada é adiantado pela bibliografia. Ao Castelo de Rebordãos apontam-se ocupações pré-históricas. Contudo, as estruturas que hoje conserva são claramente medievais.

Para além dos núcleos de povoamento e das estruturas defensivas/vigia, podemos identificar outras duas importantes evidências da organização social

12. Para estes sítios a bibliografia aponta cronologias da idade do ferro e romanas (PA). No nosso entender estas estruturas fortificadas poderão ter sido utilizadas em épocas alto medievais e talvez medievais. Mais uma vez, a classificação cronológica atribuída pelo PA tem como base dados pouco concretos, pois apenas encontraram "alguns fragmentos cerâmicos da Idade do Ferro" no sítio do Penedo (PA).

13. O sítio do Castelo, como também é designado na carta militar, é referido num documento de 1303, em que Rui Martins, alcaide de Bragança e procurador do rei, doa a 15 moradores carta de foro do vilar de Pombares, que então se chamava "Pinhel", que ficava sob Teixedo (povoação atualmente abandonada, pertencente a Pombares) para ser povoado. Na definição dos termos de Pombares, é referido o castelo sobre Veigas, que julgamos corresponder ao sítio do Castelo (Santana, 2008, pp. 91-93).

14. O Castelo de Rebordãos é referido, pela primeira vez na documentação, em 1208, no foral que lhe é atribuído por D. Sancho I. É designado por castelo de “Taurones", pertença de cavaleiros (DS, p. 271-272, Doc. 179). 
do espaço alto-medieval transmontano: as necrópoles, já mencionadas, e as vias de comunicação.

Relativamente às vias, importa referir dois importantes eixos: a incontornável via XVII do Itinerário de Antonino, que atravessa o território de Bragança no sentido este-oeste, e o Carril Mourisco, que atravessa o planalto de Miranda, no sentido norte-sul. O primeiro de origem romana e o segundo identificado como medieval, mas também como romano. Independentemente da sua origem, cremos que tanto um como outro foram percorridos ao longo dos tempos, numa região onde os grandes eixos são raros e o relevo determinante.

A via XVII, e segundo estudos anteriores (André, 2008, pp. 48-49), teria duas variantes na região de Bragança, encontrando-se numa só em Castro de Avelãs. O traçado da variante norte, passava pelas atuais aldeias ou nas suas imediações, muitas vezes, decalcado pelas estradas recentes. Se relacionarmos o seu percurso com o povoamento mais antigo, verificamos, por exemplo, que em Castrelos a via atravessaria o rio Baceiro, talvez no mesmo sítio da ponte de Castrelos, sob o controlo vigilante do Cabeço de São João, povoado fortificado, com uma ocupação de longa diacronia. Neste sítio, para além da referência a uma igreja de São João, terão sido descobertas duas sepulturas estruturadas com lajes, entretanto destruídas.

Já a variante sul, poderia passar sob o controlo do povoado fortificado do Picoto, quem sabe reutilizando antigos itinerários da Idade do Ferro. O Picoto é descrito como um povoado da Idade do Ferro, contudo não foram detetados quaisquer materiais.

Em Castro de Avelãs, a via passaria nas imediações do povoado da Torre Velha, seguindo em itinerário único para leste, passando em Bragança, a norte do castelo, e talvez na zona da ponte das Carvas, dirigindo-se para Gimonde, onde teria uma outra travessia do rio. Aqui o controlo era feito pelo Castro de Gimonde, este com vestígios romanos. Em Babe ergue-se o Castro da Sapeira, mais um povoado da Idade do Ferro, datado pela sua tipologia e por um único fragmento de cerâmica de superfície (PA). O local é um excelente ponto de controlo geoestratégico, que não terá sido ignorado em períodos posteriores. Na zona de São Julião de Palácios, a bibliografia, mais uma vez, não aponta nenhum sítio com cronologias medievais. Contudo, os povoados das Cercas ou o do Caracuto do Castro, poderiam ter um papel de vigia da via.
Do itinerário XVII partiriam vias secundárias que fariam a ligação a pontos estruturantes da economia romana, nomeadamente aos locais de extração mineira. Assim, da zona de Babe, partiria uma via em direção a sul, percorrendo o planalto de Milhão-Argozelo, região onde os vestígios de mineração são relevantes. Entre Babe e Milhão cremos que esta via passaria nas imediações dos povoados de Castragosa e Cativelo, seguindo para Milhão. Em Argozelo, existiriam caminhos de ligação a Coelhoso, atravessando o Sabor, talvez controlados pelo sítio de São Bartolomeu. Também haveria ligação a Pinelo, atravessando no sítio da Ponte Velha, controlado pelo povoado do Serro Grande de Argozelo.

O Carril Mourisco, que consideramos também estruturante, embora diferente da via XVII, atravessava o planalto de Miranda do Douro. Descendo para sul, a via passaria a ribeira da Matança, controlada pelo povoado fortificado de São Martinho de Angueira, com vestígios de romanização e seguiria até à zona de Sendim. Esta via não atravessa as atuais povoações, distando delas cerca de $2 \mathrm{kms}$.

Entre o Carril Mourisco e o rio Douro, no rebordo do planalto, haveria um outro eixo de circulação norte-sul. Entre estes dois eixos, distribuem-se grande parte dos sítios de cronologia romana e possíveis habitats de época alto medievais.

Nas arribas do Douro imperam os povoados ou estruturas fortificadas, controlando o rio, e uma rede de caminhos que os ligam, passando pelos terraços agricultados que aproveitam os pequenos cursos de água que caem no Douro. Aqui, como já vimos, também houve ocupação alto medieval.

\section{CONCLUSÃO}

Não é novidade que a paisagem medieval foi construída sob um legado tardo-antigo, adaptando realidades e operando importantes mudanças. A falta de documentos escritos e de trabalhos arqueológicos, aconselham a uma reinterpretação dos dados existentes, propondo leituras diversificadas. O povoamento alto medieval não obedeceria a uma única fórmula, adaptando-se à realidade geográfica e sociopolítica da região e do tempo. Assim, é natural uma continuidade de ocupação junto aos cursos dos rios mais importantes, eixos estruturadores e orientadores dos grandes territórios. É também natural o aproveitamento de certos espaços de exploração agrícola da Antiguidade Tardia, dos seus arrotea- 
mentos e emparcelamentos, das suas estruturas de rega e de transformação. Mas também não se deverá estranhar que tenha havido uma reocupação e/ ou reutilização de estruturas mais antigas, como os povoados fortificados, ditos "da Idade do Ferro", beneficiando da sua aparente proteção e domínio estratégico. Enfim, terão sido criados novos núcleos comunitários, muito provavelmente sob o amparo de um pequeno templo e da sua necrópole, que na alvorada de uma nova era se tornaram demasiado pequenos para uma população crescente, obrigando a transformações.

O ritmo da "modernização atual" exige uma resposta mais célere e atenta do conhecimento, sob pena de se perderem os vestígios e a memória de um passado ainda pouco explorado.

\section{BIBLIOGRAFIA}

ANDRÉ, Clara (2008) - Projecto VIAS AVGVSTAS e traçado da Via XVII do itinerário de Antonino. In Bragança um olhar sobre a História II. Bragança: Câmara Municipal de Bragança, pp. 47-55.

ANDRÉ, Clara; CARVALHO, Pedro C. (2015) - Arqueologia funerária alto medieval da Torre Velha (Castro de Avelãs, Bragança). In Identidad y Etnicidad en Hispania: Propuestas teóricas y cultura material en los siglos V-VIII. Documentos de Arqueología Medieval 8. Euskal Herriko Unibertsitatea. Universidad del País Vasco, pp. 145-16o.

BOLÓS, Jordi (2015) - Paisatges i transicions: canvis i continuitats al llarg de la història. In El paisatge en èpoques de transició al llarg dels darrers dos mil anys. Territori i Societat: el paisatge històric. Universitat de Lleida. (Història, Arqueologia, Documentació. VII), pp. 59-126.

CAPELA, Mafalda; GARCIA, Maria; LOPES, Lídia; MENÉNDEZ, Jorge; SALGADO, Mónica (2004) - Trabalhos Arqueológicos no âmbito da Sociedade Bragança Polis. In Bragança um olhar sobre a História. Bragança: Câmara Municipal de Bragança, pp. 31-94.

DS Documentos de D. Sancho I (1174-1211). Rui de Azevedo; P. Avelino de Jesus da Costa; Marcelino Rodrigues Pereira (Edição). Coimbra: Universidade de Coimbra. 1979. Vol. I, p. 49-51 - Doc. 31; p. 118-119, Doc. 76; p. 271-272 - Doc. 179.

GOMES, Rita Costa (2003) - Castelos da Raia: Trás-os-Montes. Lisboa: Ministério da Cultura. Instituto Português do Património Arquitectónico. Vol. II. (Colecção Arte e Património).

GTT As Gavetas da Torre do Tombo. A. da Silva Rego (Edição). Lisboa: Centro de Estudos Históricos Ultramarinos. Vol. II. Gav. III-XII. 1962, p. 657 - Doc. 1824.
GUTIÉRREZ GONZÁLEZ, J. Avelino (2017) - Processos de formación de ciudades altomedievales en el norte peninsular. In O papel das pequenas cidades na construção da Europa Medieval. Estudos 17. IEM - Instituto de Estudos Medievais / Câmara Municipal de Castelo de Vide, pp. 19-85.

LEMOS, Francisco de Sande (1993) - Povoamento Romano de Trás-os-Montes Oriental. Braga: Universidade do Minho (Dissertação de Doutoramento na especialidade de Pré-História e História da Antiguidade).

MARTÍN VISO, Iñaki (2001) - La articulación des poder en la cuenca del duero: el ejemplo del espacio zamorano (siglos VI-X). In Anuario de Estudios Medievales. 31: 1, pp. 75-122. (Disponível em https://doi.org/10.3989/aem.2001.v31.i1).

PA Portal do Arqueólogo disponível em: https://arqueologia.patrimoniocultural.pt.

PMH-Inq. Portugaliae Monumenta Historica - Inquisitiones. Inquirições Gerais de D. Afonso III 1258. Lisboa: Academia das Ciências. Vol. I. Pars II. Fascículo VIII. Quarta Alçada. 1961, pp. 1280-1345.

SANTANA, Maria Olinda Rodrigues (2008) - Documentação foraleira dionisina de Trás-os-Montes: breve estudo e edição interpretativa. Lisboa: Edições Colibri, pp. 91-93.

TENTE, Catarina (2017) - Alta Idade Média no Vale do Tua: continuidades e mudanças entre o fim do Império Romano e o início da nacionalidade. In Estudo Histórico e Etnográfico do Vale do Tua (Concelhos de Alijó, Carrazeda de Ansiães, Mirandela, Murça e Vila Flor). Aproveitamento Hidroelétrico de Foz Tua. EDP. Porto. Vol. II, pp. 4-57.

TERESO, Sofia; BRITO, André; UMBELINO, Cláudia; CIPRIANO, Miguel; AMDRÉ, Clara; CARVALHO, Pedro C. (2015) - Arqueologia funerária alto medieval da Torre Velha (Castro de Avelãs, Bragança). In Identidad y Etnicidad en Hispania: Propuestas teóricas y cultura material en los siglos V-VIII. Documentos de Arqueología Medieval 8. Euskal Herriko Unibertsitatea. Universidad del País Vasco, pp. 145-16o. 


\section{ANEXOS}

(pontos que estão nos 4 mapas)

MIRANDA DOURO: 1-Faceiras da Granja; 2-Fonte Amador; 3-Senhora Monte; 4-Urreta da Malhada; 5-Vinha do Padre; 6-Castro do Cércio; 7-Santa Maria de Cércio; 8-Santo André; 9-Via Romana; 10-Via RomanaII; 11-Castro Vale de Águia; 12-Raio; 13-São João das Arribas; 14-Coroa; 15-Via Romana; 16-Santos; 17-Capela de São Paulo; 18-Trampas Carreiras; 19-Navalhos; 20-Castrolouço; 21-Nossa Senhora da Assunção; 22-Toural; 23-Penhal do Castro; 24-Picão do Diabo; 25-Picão da Penha Alva; 26-Castelar; 27-Necrópole Igreja de Picote; 28-Via Romana; 29-Via Romana; 30-Cigadonha; 31-Castrilhouço da Braceosa; 32-Castralheiras; 33-Casicas; 34-Capela de Santo Albino; 35-Necrópole Igreja Vila Chã Braciosa; 36-Abadia; 37-Santo Eustáquio; 38-Touro; 39-Castrilhouço; 40-Penha da Torre; 41-Senhora da Luz; 42-São Martinho de Angueira; 43-Via Romana; 44-Via Romana. VIMIOSO:45-Via Romana; 46-Castelo dos Mouros; 47-Castelo de Algoso; 48-Penenciada; 49-Cabeço da Forca; 5o-São Martinho; 51-Castelo Velho; 52-Terronha; 53-Castro dos Mouros; 54-Batoqueira; 55-Castelo; 56-São Mamede; 57-Penedo da Abrunheira; 58-Pedras Altas; 59-Rebolo; 60-Caminho Romano; 61-Gago; 62-Cabeço da Cocolha; 63-São Miguel; 64-Santa Marinha; 65-Picoto; 66-Lagoaço; 67-Canto da Serra; 68-Castro do Serro Grande; 69-Terronha; 70-São Bartolomeu. BRAGANÇA: 71-Castelo; 72-Santa Eulália; 73-Castelo dos Mouros; 74-Povoado do Castelo dos Mouros; 75-São Justo; 76-Castelo do Sanguinho; 77-Mata Mouros; 78-Castro do Serro de Coelhoso; 79-Castrilhão de Coelhoso; 8o-Castro de Coelhoso; 81-Cabeço da Terronha; 82-Castro de Vila Boa; 83-Senhora do Aviso; 84-Trás do Souto; 85-São Julião; 86-Terronha; 87-Castelo; 88-São Miguel; 89-Pombares; 90-Cabeço do Cercado; 91-Lombo da Igreja; 92-Eiró de Sortes; 93-Castro Mau; 94-Castro de Ciragata; 95-Castelinho; 96-Muradelhas; 97-Lameiro da Anta; 98-Senhora da Conceição; 99-Ferradoza; 10o-Fonte de À Mó; 101-Cabeço da Mêda; 102-Fraga do Cavaleiro; 103-Estrepelgo; 104-Castelo de Alfenim; 105-Cortinha do Castelo; 106-Souto da Capela; 107-Penedo; 108-Cabeço das Freiras; 109-Castelinho; 110-Torre de Medorro; 111-Castro Mouro; 112-Barrocal; 113-Crasto; 114-Castelo dos Mouros; 115-Cativelo; 116-Buraco da Moura; 117-Igreja São Lourenço de Milhão; 118-Cabecinho dos Mouros; 119-Senhora da Veiga; 120-Sumidago; 121-Castanheiro do Senhor; 122-Monte dos Xistos; 123-Quinta de São Lourenço; 124-Alto do Martim Cansado; 125-Castelo de Rebordãos; 126-Ferradal; 127-Vale das Pereiras; 128-Cigadonha; 129-Sampaio; 130-Izei; 131-Senhora da Serra; 132-Castelinho; 133-Castro da Seara/; 134-Picoto; 135-Castelo de Alimonde; 136-Terronha de Alimonde; 137-São Martinho de Carrazedo; 138-Canada de Alimonde; 139-Santo Amaro de Alimonde; 140-Escalões de Alimonde; 141-Cabeço de São João; 142-Igreja Velha de Conlelas; 143-Fragas do Castelo; 144-São Cláudio; 145-Torre Velha Castro Avelãs; 146-Via XVII; 147-São Martinho; 148-Devesa; 149-Sagrado; 150-Quinta de Britelo; 151-São Tiago de Lagomar; 152-São Salvador; 153-São Bartolomeu; 154-Igreja de Santa Maria; 155-Necrópole da Igreja de São Vicente; 156-Necrópole da Igreja de São João; 157-Necrópole Convento São Francisco; 158-Mata de São Sebastião; 159-Castro de Gimonde; 16o-Castro de Baçal; 161-Castro Sacóias; 162-Castro de Sacóias/Senhora da Assunção; 163-Castragosa; 164-Castro da Sapeira; 165-Monte Cercado; 166-São Pedro; 167-São Sebastião; 168-Fragas do Castro; 169-Cercas; 17o-Caracuto do Castro; 171-Caminho das Doñas; 172-Castro; 173-Cabeço dos Mouros; 174-Fragas do Cabril 1; 175-Vale de Igrejas/; 176-Alto do Castro; 177-Torre; 178-Chaira; 179-Lombeiro Branco; 180-Torre do Castro; 181-Sagrado; 182-Lombeiro dos Maquieiros; 183-Vinha do Santo; 184-São Salvador de Oleiros; 185-Castelo dos Mouros; 186-Alto dos Currais; 187-Ruínas Senhora da Hera; 188-Santo Amaro; 189-Santo André Velho; 190-São Tomé; 191-Alto da Torre; 192-Castro de Zeive; 193-Castelo das Olgas/Urreta Formosa. 


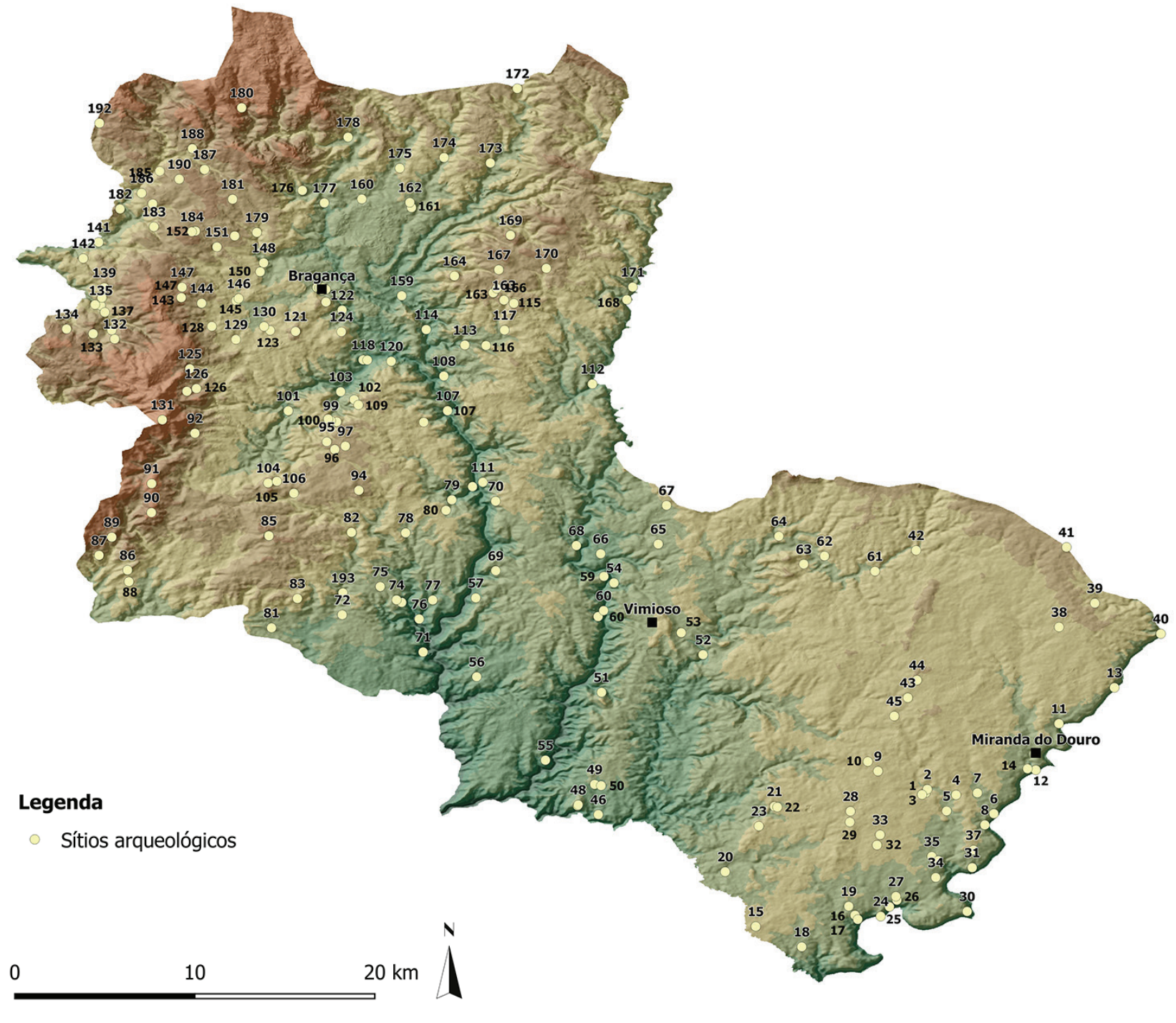

Mapa 1 - Sítios arqueológicos. Autor: César Guedes. 


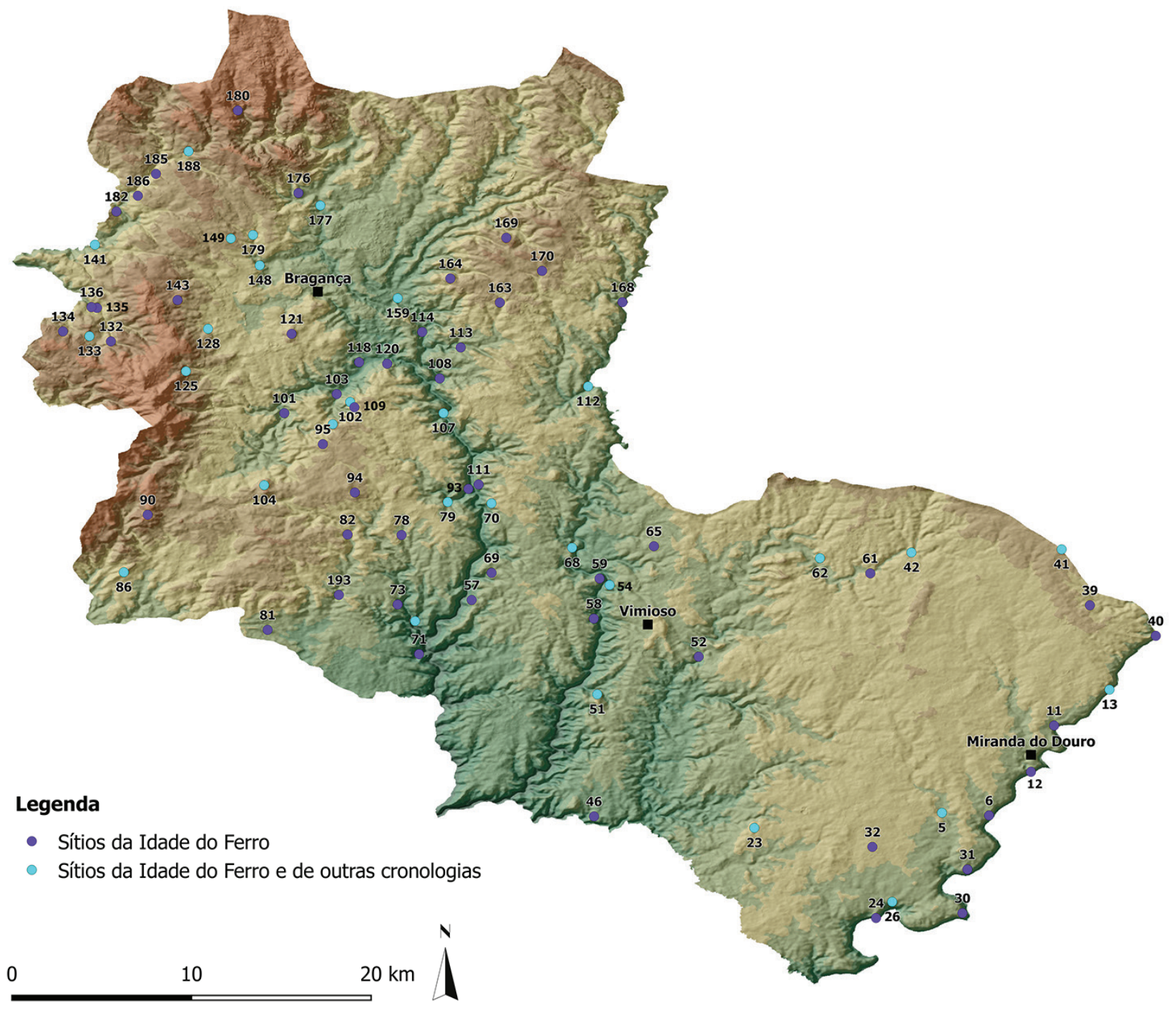

Mapa 2 - Sítios de cronologias da Idade do Ferro. Autor: César Guedes 


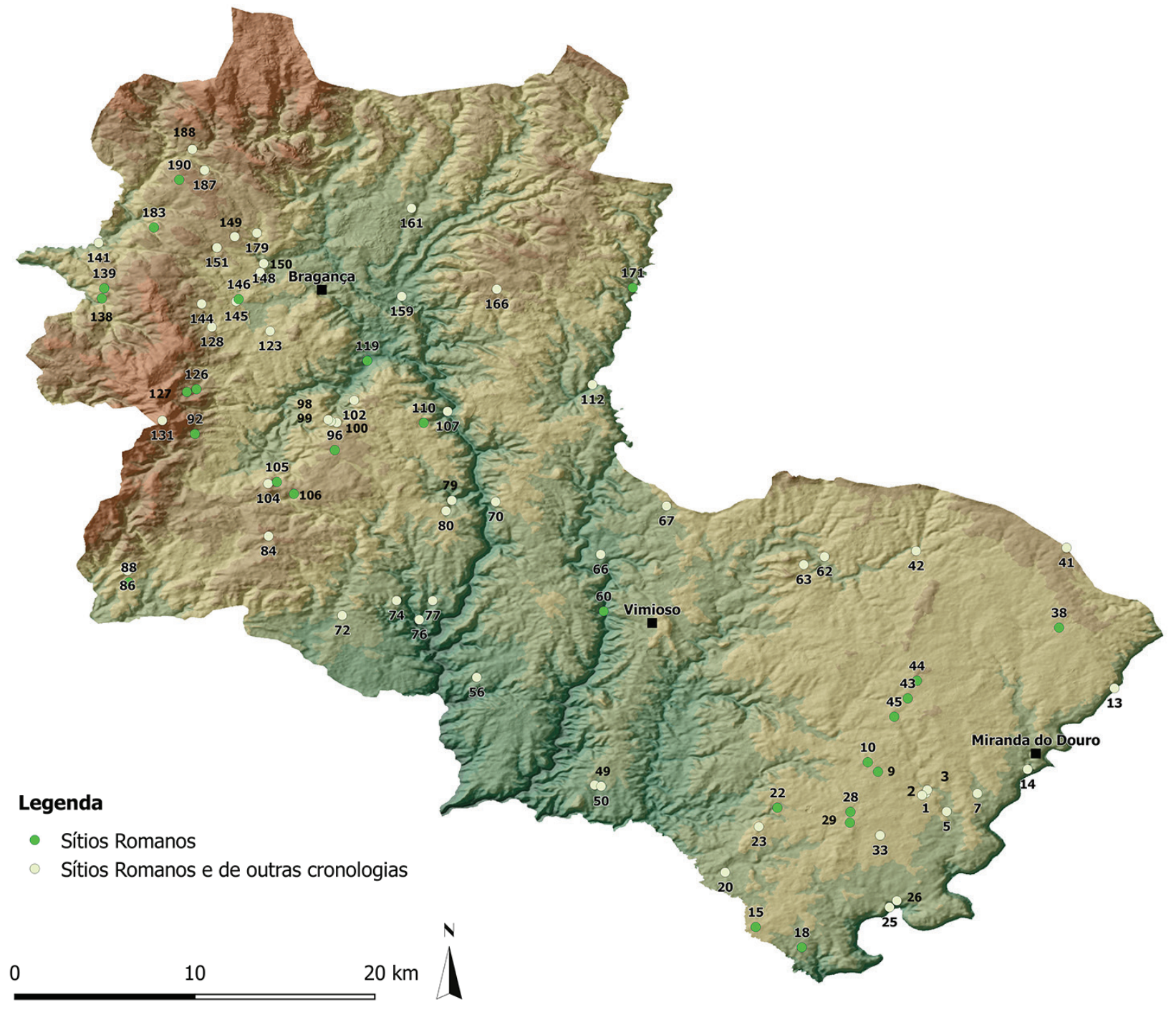

Mapa 3 - Sítios de cronologias Romanas. Autor: César Guedes. 


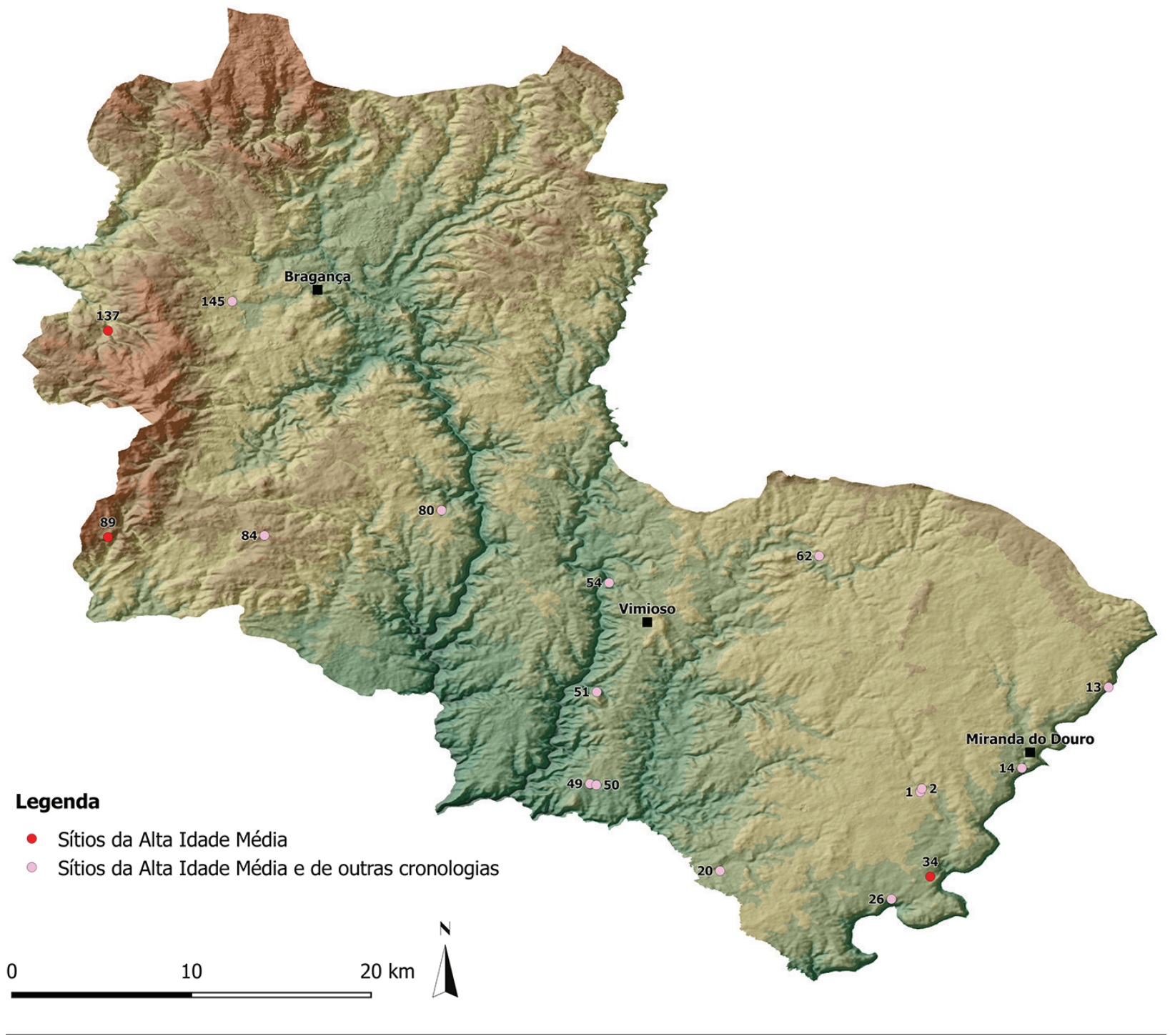

Mapa 4 - Sítios de cronologias da Alta Idade Média. Autor: César Guedes. 


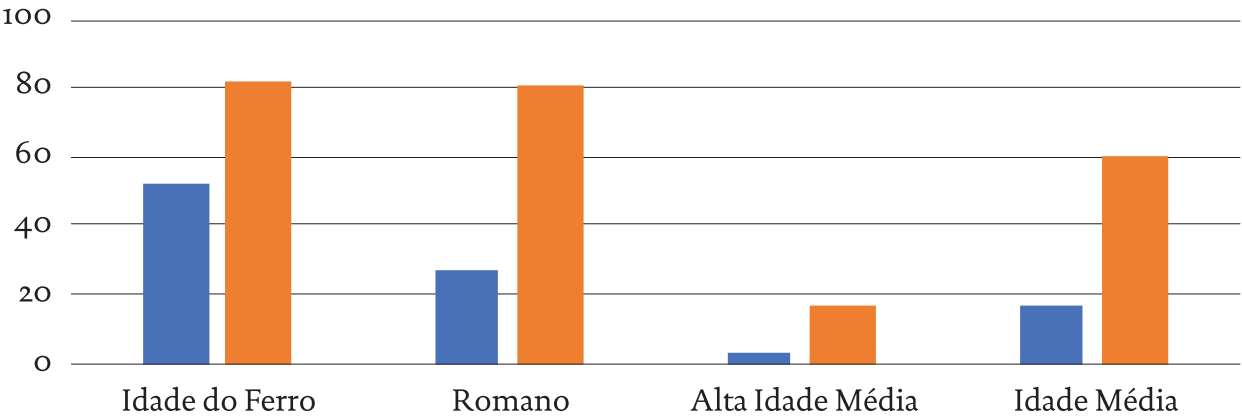

- Ocorrências com cronologia exclusiva

Total com as ocorrências com cronologias diacrónicas

Gráfico 1 



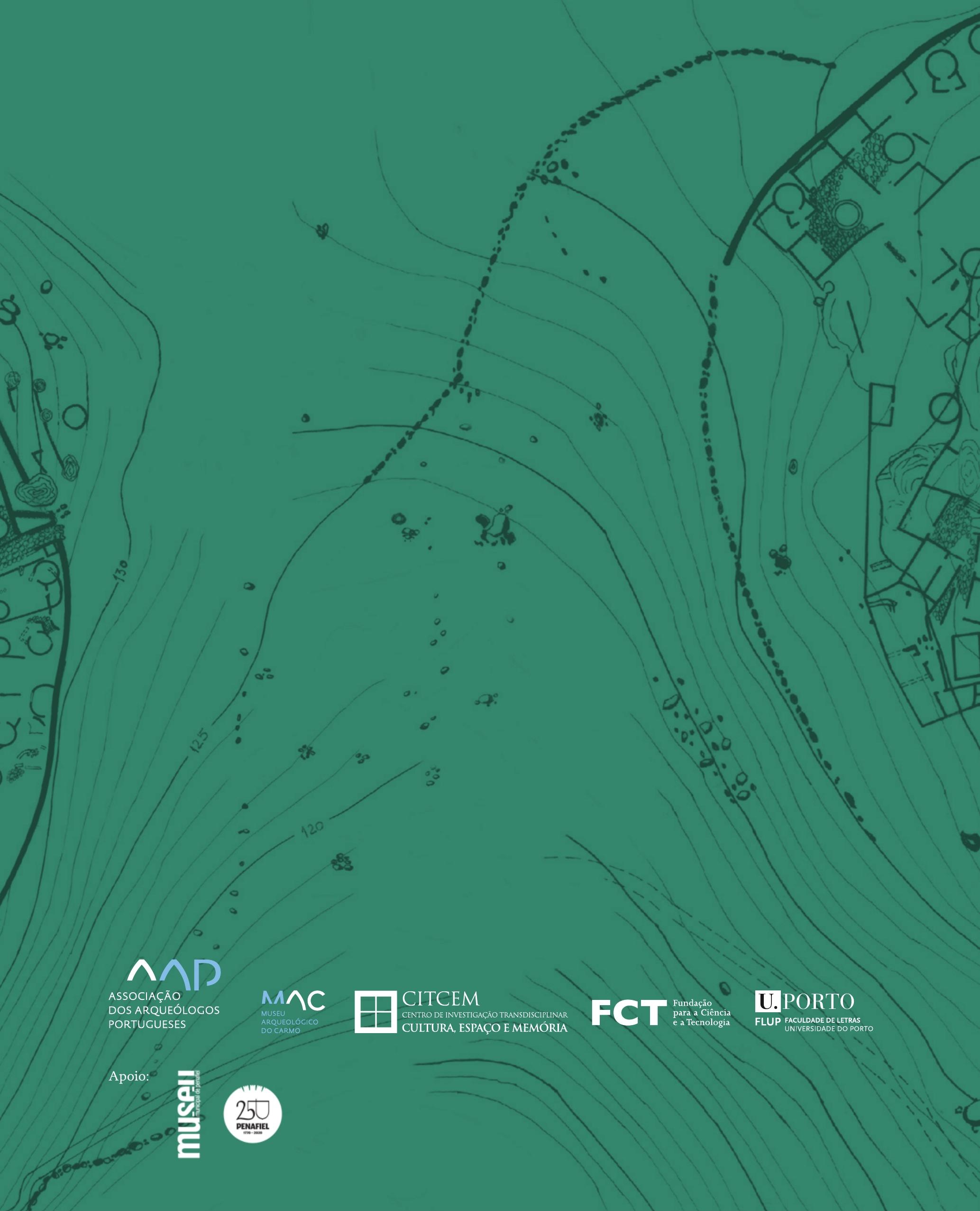

